\title{
ODREĐIVANJE VISINE NAKNADE ŠTETE U MEĐUNARODNOJ INVESTICIJSKOJ ARBITRAŽI $S$ OBZIROM NA UTVRĐENU POVREDU I METODU IZRAČUNA
}

Sažetak: $\quad$ Međunarodna investicijska arbitraža kao alternativni način rješavanja sporova između stranih investitora $i$ država primateljica investicije ujedno je i omiljeni način rješavanja spora za investitore. Ona se sastoji od tri dijela postupka, koji se svi mogu zasebno raspravljati, a to su pitanje nadležnosti, pitanje osnovanosti tužbenog zahtjeva i pitanje reparacije štete. Slijedom navedenoga moguće je da tribunal u takvom postupku donese jedan, dva ili čak tri arbitražna pravorijeka, ovisno o tome je li došlo do razdvajanja postupaka. To pokazuje koliko je svaka od faza postupka složena. Rad se bavi pitanjem reparacije štete i posebno naknadom štete kao glavnim oblikom reparacije štete. Daje se prikaz pravnih pitanja koja utječu na visinu naknade štete, glavnih metoda izračuna naknade štete kao i relevantnih odluka i statističkih podataka u odnosu na navedena pravna pitanja i metode izračuna visine štete. Zagovara se proaktivni integralni pristup određivanju visine naknade štete koji će uključiti detaljnu analizu činjeničnog stanja kako bi se spor pravilno pravno kvalificirao i kako bi se pravilno odredila najbolja metoda izračuna naknade štete.

Ključne riječi: $\quad$ arbitraža, metode izračuna naknade štete

\section{UVOD}

Međunarodna investicijska arbitraža alternativni je način rješavanja sporova (alternativa sudskoj zaštiti) u kojem je tužena država u kojoj se ostvaruje investicija dok je tužitelj strani in-

Jadranka Osrečak, mag. iur., zamjenica općinskog državnog odvjetnika u Zagrebu upućena na rad u Državno odvjetništvo Republike Hrvatske, Gajeva 30a, 10000 Zagreb. Adresa e-pošte: osrecak@gmail.com. ORCID: https://orcid.org/0000-00030156-8725. 
vestitor koji investiciju ostvaruje. To je najčešće birani način rješavanja sporova kod investitora jer im omogućava da spor s državom iznesu pred međunarodno sudište, a ne pred nacionalni sud države koju tuže, pa ne iznenađuje činjenica da su investitori, prema podatcima Komisije Ujedinjenih naroda za trgovinu i razvoj (dalje UNCTAD) izabrali upravo taj način rješavanja spora u čak 1061 predmeta (Graf 1). U 37\% slučajeva tribunal je odlučio u korist države, a spor je završio nagodbom u 20\% (Graf 2) pri čemu je pri sklapanju nagodbi zasigurno posebno značajna bila uloga vještaka u dijelu koji se odnosi na visinu naknade za koju su se stranke nagodile. I u predmetima koji su odlučeni u korist investitora (29\% - Graf 2), kao što će i daljnja analiza pokazati, bitna je uloga vještaka, ali i tribunala i samih stranaka u odnosu na poznavanje metoda izračuna visine štete jer o njihovoj pripremljenosti, poznavanju prava i metoda izračuna štete ovisi i konačni ishod spora u odnosu na visinu štete koju je država obvezna platiti.

Graf 1: Broj i status investicijskih arbitraža (uključuje 1104 postupka, prema podatcima 31. prosinca 2020. ${ }^{1}$ ):

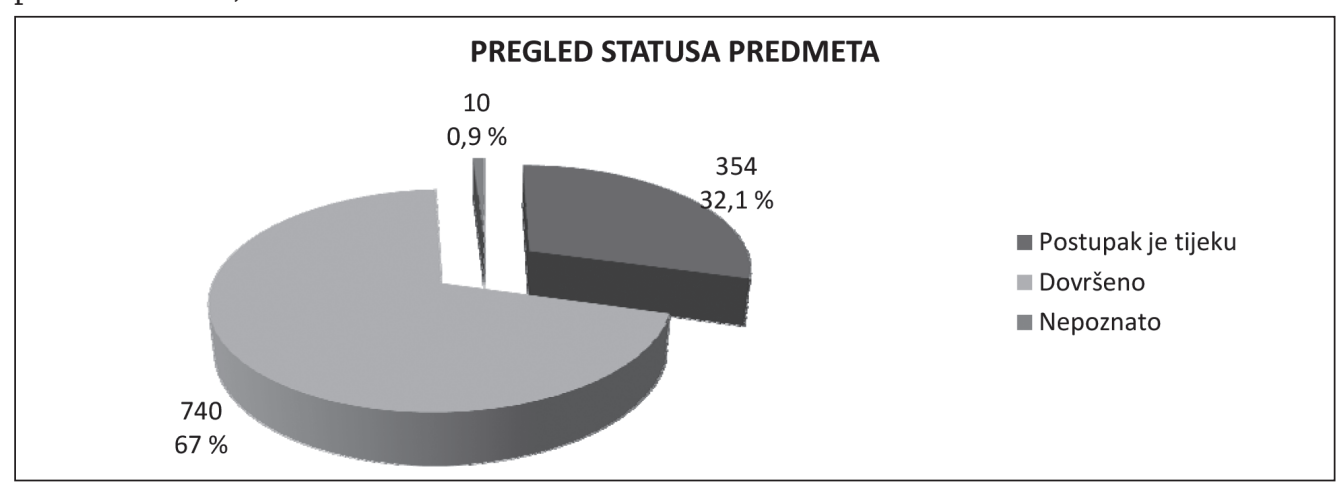

Graf 2: Pregled prema ishodu postupka u 740 dovršenih arbitražnih postupaka: ${ }^{2}$

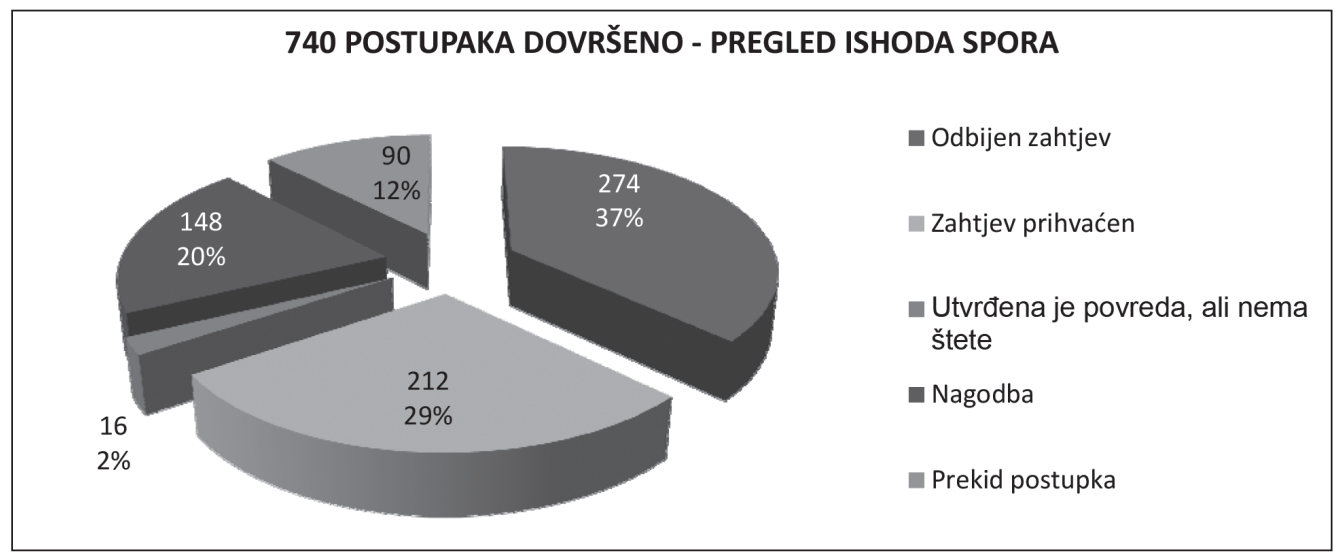

1 Podatci s UNCTAD-ovih mrežnih stranica: https://investmentpolicy.unctad.org/investment-dispute-settlement?status=1.

2 Podatci su analizirani prema informacijama o dovršenim predmetima koji su dobiveni s UNCTAD-ovih mrežnih stranica: https:// investmentpolicy.unctad.org/investment-dispute-settlement?status=100. 
Naknada štete, kao treći dio arbitražnog postupka (svaki arbitražni postupak sastoji se od utvrđivanja nadležnosti, osnovanosti zahtjeva i konačno visine naknade štete) iznimno je bitan u investicijskim arbitražama i iz aspekta da se naknada štete isplaćuje iz državnog proračuna, a činjenica da je investitor uspio dokazati da je do povrede došlo, ali pritom nije uspio dokazati da mu je nastupila šteta ili je dosuđena šteta tek mali fragment tužbenog zahtjeva, može imati odvraćajući efekt na investitore pri odlučivanju da pokrenu arbitražni postupak protiv države. U radu se analizira utjecaj pravilnog pravnog kvalificiranja spora i metode izračuna štete $u$ odnosu na visinu dosuđene naknade štete kao i statistički podaci u odnosu na utuženu i dosuđenu visinu štete jer postupak utvrđivanja naknade štete počiva na pravnim i ekonomskim temeljima. Pravni temelj odnosi se mahom na međunarodne ugovore kao osnove međunarodne odgovornosti država kao i na samo međunarodno običajno pravo iz kojega proizlazi obveza države da reparira štetu zbog povrede. Upravo stoga je poznavanje pravnih načela - mogućih povreda prema međunarodnom pravu i ekonomskih principa - načina izračuna naknade štete ključno za određivanje visine naknade štete.

\section{RAZVOJ INVESTICIJSKE ARBITRAŽE - OSVRT NA MEĐUNARODNE UGOVORE I KONVENCIJE TE MEĐUNARODNO OBIČAJNO PRAVO KAO TEMELJ ODGOVORNOSTI DRŽAVE ZA NAKNADU ŠTETE}

Prije opisa pravnih standarda zaštite potrebno je nakratko osvrnuti se na razvoj zaštite stranaca (pa tako i stranih investitora) kao posebnog polja međunarodnoga prava. Pri tomu treba imati u vidu da su, prema članku 38. Statuta Međunarodnog suda pravde, ${ }^{3}$ izvori međunarodnog prava (dakle i prava koja se odnose na strane investitore) međunarodne konvencije, međunarodno običajno pravo, opća načela prava priznata od strane civiliziranih naroda kao i odluke (međunarodnih) sudišta (uključujući i tribunala) te radovi eminentnih pravnih stručnjaka. ${ }^{4}$ Za potrebe rasprave o pravnim standardima zaštite prava stranaca i odgovornosti države za naknadu štete, prije prikaza pravnih standarda, u ovom se poglavlju daje kratki pregled razvoja međunarodnih instrumenata kao izvora prava te međunarodnog običajnog prava kao izvora prava za vrstu reparacije štete.

\section{MEĐUNARODNI UGOVORI I KONVENCIJE KOJIMA SE ŠTITE PRAVA STRANIH INVESTITORA - KRATAK PREGLED POVIJESNOG RAZVOJA}

U začetku razvoja investitori iz razvijenih zemalja inzistirali su na pristupu da sve države, bez obzira na dosegnuti stupanj razvoja, postupaju prema strancima u skladu s tzv. minimalnim standardom postupanja jer je to obveza koja proizlazi iz međunarodnog običajnog prava.

3 Statute of the International Court of Justice (International Court of Justice) < www.icj-cij.org/en/statute> pristupljeno 19. srpnja 2021.

4 Više o izvorima međunarodnog prava vidi u Moshe Hirsch, 'Sources of International Investment Law' in Andrea K Bjorklund and August Reinisch (eds), International Investment Law and Soft Law (Edward Elgar Publishing 2012) 9-38. 
Minimalni standard postupanja (uz koji se veže definiranje FET standarda - Fair and Equitable Treatment o kojem će biti riječi kasnije u tekstu) formuliran je prvi put u međunarodnom pravu u odluci Američko-meksičke komisije iz 1926. u predmetu L. F. H. Neer i Pauline Neer (SAD) c/a Meksiko koja u tom dijelu navodi: ${ }^{5}$ „Postupanje prema strancu mora predstavljati grubu povredu, zlu namjeru, namjerno zanemarivanje obveza ili nedostatne vladine mjere koje su toliko suprotne međunarodnim standardima da bi svaka razumna ili nepristrana osoba okvalificirala te mjere kao nedostatne.“

Slijedom navedenoga investitori su ustrajali na tvrdnji da kada domaće pravo zemlje pruža niže standarde zaštite, stranci u toj zemlji i dalje imaju pravo na minimalni standard postupanja prema međunarodnom pravu.

Ovu tvrdnja neki su teoretičari žestoko pobijali. U toj grupi posebno se isticao poznati argentinski pravnik Carlos Calvo koji je tvrdio da razvijene države ne mogu inzistirati na tome da zemlje domaćini tretiraju strance (investitore) bolje od vlastitih državljana (tzv. Calvova doktrina).

Nesuglasice u pristupu pravima stranih investitora došle su posebno do izražaja u radu Ujedinjenih naroda gdje je 70-ih godina prošlog stoljeća Opća skupština Ujedinjenih naroda prihvatila rezolucije 3201, 3202 i 3281. Cilj tih rezolucija bio je uspostavljanje novog međunarodnog ekonomskog poretka i izrada Povelje o ekonomskim pravima i dužnostima država. Povelja je trebala propisati primjenu nacionalnog prava i na strane ulagače, sukladno Calvovoj doktrini. Nadalje, Povelja je trebala propisati da se naknada za izvlaštenje i nacionalizaciju također ima odrediti prema nacionalnim zakonima i propisima - dakle visina štete pri nezakonitom izvlaštenju bila bi određena nacionalnim pravom zemlje primateljice investicije.

Rezolucije 3201, 3202 i 3281 rezultirale su velikom pravnom nesigurnošću što je bilo štetno za sve sudionike uključene u izravna strana ulaganja, dakle ne samo za strane investitore, već i za nerazvijene države i države u razvoju koje su u velikoj mjeri ovisile o stranim investicijama kako bi unaprijedile gospodarski razvoj. Naime, razvijene zemlje i investitori iz tih zemalja htjeli su pod svaku cijenu izbjeći da navedene rezolucije postanu dio međunarodnog običajnog prava. Budući da su u to doba prevagu u Općoj skupštini Ujedinjenih naroda (u čiju nadležnost spada i razvoj i kodifikacija međunarodnog prava) imale zemlje u razvoju i nerazvijene zemlje (bivše kolonije), investitori iz razvijenih zemalja prestali su u njih izravno ulagati.

Rješenje nesigurnosti proizašlih iz rezolucija UN-a i novonastale situacije u kojoj su razvijene zemlje i investitori iz tih zemalja pod svaku cijenu htjeli izbjeći stvaranje novoga međunarodnog ekonomskog poretka koji je promovirao pravednu raspodjelu svjetskog bogatstva proizašao je, među ostalim, iz međunarodnih ugovora te dviju konvencija (Konvencija o priznanju i ovrsi stranih arbitražnih pravorijeka iz 1958. godine tj. NY konvencija ${ }^{6}-159$ zemalja ratificiralo je Konvenciju uključujući i Republiku Hrvatsku i Konvencija o rješavanju investicijskih sporova između država i državljana drugih država iz 1965. godine, tj. Washingtonska

$5 \quad$ LFH Neer and Pauline Neer (USA) $v$ United Mexican States, (15 October 1926) Reports of International Arbitral Awards (2006, vol IV) 60-66.

6 Vidi Status: Convention on the Recognition and Enforcement of Foreign Arbitral Awards (New York, 1958) (the "New York Convention") 〈https://uncitral.un.org/en/texts/arbitration/conventions/foreign_arbitral_awards/status2〉 pristupljeno 19. srpnja 2021. 
ili ICSID konvencija ${ }^{7}$ - 164 zemlje potpisalo je i ratificiralo Konvenciju uključujući i Republiku Hrvatsku).

U središtu rješenja bili su međunarodni ugovori i to međudržavni bilateralni ugovori o promociji i zaštiti stranih investitora koji su garantirali određeni standard postupanja i zaštite zemlje primateljice investicije investitorima iz zemlje ugovornice (tzv. BIT-ovi - Bilateral Investment Treaty).

Europski su BIT-ovi u to vrijeme u velikoj mjeri bili modelirani prema nacrtu Konvencije o zaštiti stranih ulaganja iz 1967. koju je pripremila Organizacija za ekonomsku suradnju i razvoj (OECD). Ti su BIT-ovi najčešće sadržavali obveze za države, a ne i za strane investitore i iako su promovirali načelo reciprociteta, u stvarnosti su djelovali gotovo isključivo u svrhu zaštite investitora iz razvijenih država jer su jedino oni i ulagali u inozemstvu.

Od zaključivanja prvih BIT-ova puno se toga promijenilo. Značajno je obilježje toga razvoja da su države u razvoju također počele zaključivati BIT-ove između sebe. Također, investitori iz zemalja u razvoju počeli su ulagati u razvijene države. Kao rezultat toga, arbitražne su postupke počeli pokretati ne samo investitori iz razvijenih zemalja nego i investitori iz zemalja u razvoju protiv razvijenih država. Zbog toga su razvijene države preformulirale svoje modele BIT-a (npr. SAD).

Koliko su BIT-ovi važni u zaštiti prava stranih investitora i razvoja standarda zaštite, govori i činjenica da je dosad u svijetu potpisano 2844 BIT-a, a na snazi ih je $2290,{ }^{8}$ da je u svijetu potpisano 420 multilateralnih sporazuma koji sadrže odredbe o zaštiti stranih investitora, a na snazi ih je $324,{ }^{9}$ kao i da je dosad poznato 1104 međunarodna investicijska arbitražna postupka ${ }^{10}$ koji su proizašli iz BIT-ova ili multilateralnih sporazuma (najviše Ugovora o energetskoj povelji ${ }^{11}$ i NAFTA-e ${ }^{12}$ ).

BIT-ovi, baš kao i multilateralni sporazumi kao npr. Energetska povelja, ${ }^{13}$ CAFTA-DR $^{14}$ ili NAFTA,${ }^{15}$ propisuju materijalnopravnu i postupovnopravnu zaštitu stranih investitora.

Materijalnopravna zaštita očituje se u pravnim standardima postupanja prema strancima o kojima će biti riječi u drugom poglavlju rada.

Postupovnopravna zaštita prava stranih investitora proizlazi iz činjenice da BIT-ovi i multilateralni ugovori propisuju način rješavanja sporova koji najčešće uključuje, uz pravo na tuž-

7 Vidi Database of ICSID Member States (International Centre for Settlement of Investment Disputes) <https://icsid.worldbank.org/ about/member-states/database-of-member-states> pristupljeno 19. srpnja 2021.

8 Vidi International Investment Agreements Navigator (United Nations Commission on International Trade Law, Investment Policy Hub,) <https://investmentpolicy.unctad.org/investment-dispute-settlement> pristupljeno 19. srpnja 2021.

9 Ibid.

10 Ibid.

11 The International Energy Charter - Consolidated Energy Charter Treaty: With Related Documents (last updated 15 January 2016) <www.energycharter.org/fileadmin/DocumentsMedia/Legal/ECTC-en.pdf> pristupljeno 19. srpnja 2021.

12 North American Free Trade Agreement (NAFTA) <www.sice.oas.org/trade/nafta/naftatce.asp> pristupljeno 19. srpnja 2021.

13 Ibid.

14 Poglavlje 10 Central America Free Trade Agreement (CAFTA) <https://ustr.gov/trade-agreements/free-trade-agreements/caftadr-dominican-republic-central-america-fta/final-text> pristupljeno 19. srpnja 2021. 
bu pred nacionalnim sudom, i pravo stranih investitora da u slučaju povrede iniciraju međunarodnu investicijsku arbitražu.

Arbitraža predviđena BIT-ovim i multilateralnim ugovorima javlja se ili kao institucionalna arbitraža pri institucijama kao što su Međunarodni centar za rješavanje ulagačkih sporova (ICSID-om) osnovanim pri Svjetskoj banci kao jednoj od sastavnica Ujedinjenih naroda (dalje: UN), Stalnim arbitražnim sudištem sa sjedištem u Hagu (Permanent Court of Arbitration), Trgovačkom komorom u Stockholmu (Stockholm Chamber of Commerce), Međunarodnom trgovačkom komorom u Parizu (International Camber of Commerce) itd. ili kao ad hoc arbitraža prema (najčešće) UNCITRAL arbitražnim pravilima.

Međunarodna investicijska arbitraža na temelju Konvencije o rješavanju investicijskih sporova između država i državljana drugih država (Washingtonska ili ICSID konvencija), kao transnacionalna i delokalizirana arbitraža, najčešći je način rješavanja sporova između investitora i država primateljica investicije jer je u potpunosti odvojena od sudova, tj. i postupak pobijanja arbitražnog pravorijeka ne vodi se pred nacionalnim sudom mjesta arbitraže nego pred odborom koji imenuje ISCID.

\section{MEĐUNARODNO OBIČAJNO PRAVO KAO OSNOVA ODGOVORNOSTI DRŽAVA ZA POVREDU MEĐUNARODNIH UGOVORA I REPARACIJU ŠTETE}

Pitanje odgovornosti države za povredu međunarodnoga prava proizlazi iz međunarodnoga običajnog prava kodificiranoga u Nacrtu članaka o međunarodnoj odgovornosti država za nedopušteno postupanje (Draft articles on Responsibility of States for Internationally Wrongful Acts), koji je pripremila UN-ova Međunarodna komisija za pravo i koji je prihvaćen u UN-ovoj Rezoluciji Generalne skupštine broj 56/83. ${ }^{16}$

Iako rezolucije Generalne skupštine u pravilu nisu obvezujuće, činjenica da u tom slučaju rezolucija kodificira međunarodno običajno pravo koje se smatra primarnim izvorom međunarodnoga prava, značit će u praksi da će ju međunarodna sudišta primjenjivati.

Nacrt članaka o međunarodnopravnoj odgovornosti država (dalje: Nacrt članaka ili Nacrt članaka o međunarodnoj odgovornosti država) u članku 31. propisuje obvezu države da reparira sve vidove štete u slučajevima kada je utvrđena povreda, a u članku 34. razrađuje da obeštećenje (reparacija) može biti u vidu restitucije - restitutio in integrum, plaćanja naknade štete - tzv. kompenzacija i satisfakcije - javnoga priznanja da je počinjena povreda međunarodnoga prava.

Restitucija (restitutio in integrum) je glavni oblik reparacije štete kojom bi povrijeđena strana (strani investitor) trebala biti stavljena u poziciju kao da do povrede nije ni došlo. U investicijskoj međunarodnoj arbitraži taj je oblik reparacije štete rijedak jer je upitno koliko bi sudovi

16 United Nations, Resolution adopted by the General Assembly A/RES/56/83 (28 January 2002) <https://undocs.org/A/ RES/56/83> pristupljeno 19. srpnja 2021. 
zemlje koja je tužena zbog povrede prava stranoga investitora bili spremni provesti odluku međunarodnoga tribunala kojim se nalaže uspostava stanja prije utvrđene povrede. ${ }^{17}$

Tribunali nisu skloni nalagati restituciju kada je riječ o povredi prava investitora radi mjera države, a i u trenutku kada strani investitor pokreće postupak protiv države u kojoj ostvaruje investiciju, jasno je da će teško biti uspostaviti prijašnje stanje s obzirom na to da ili više nema međusobnoga povjerenja ili je investitor već napustio investiciju ili oboje. ${ }^{18}$

Upravo činjenica da je restitucija najčešće nemoguća kao glavni oblik reparacije štete nametnula se naknada štete regulirana člankom 36. Nacrta članaka. Reparacija štete kroz kompenzaciju sastoji se u naknadi materijalne štete te u naknadi izgubljene dobiti i nematerijalne štete.

Iz svega navedenoga vidljivo je da je međunarodna investicijska arbitraža prema svojim karakteristikama složen sustav koji dijelom počiva na postulatima trgovačke arbitraže, na međunarodnom javnom pravu te utjecajima anglosaksonskoga i kontinentalnoga prava na postupak, s time da je u području naknade štete, kroz predmet Chorzow, ${ }^{19}$ čiji su postulati vezani za obeštećenje u slučaju povrede međunarodnoga prava ugrađeni i u Nacrt članaka, vidljiv utjecaj kontinentalnoga prava dok se utjecaj anglosaksonskoga prava posebno očituje u činjenici da je riječ o akuzatornom postupku u kojem su stranke, svjedoci i eksperti izloženi unakrsnom ispitivanju.

\section{ZAŠTITA STRANIH INVESTITORA - PRAVNI STANDARDI}

Materijalnopravna zaštita stranih investitora proizlazi iz BIT-ova, multilateralnih međunarodnih ugovora koji sadrže odredbe o zaštiti prava stranih investitora te nacionalnih propisa u kojima zemlje propisuju zaštitu stranih investicija i investitora.

Odgovornost države proizlazi iz njezinih acta iure imperii, dakle iz postupanja države u kojima ona izvršava svoju suverenu vlast bilo kroz zakonodavnu (regulatornu) djelatnost države, bilo kroz upravne akte ili sudske odluke, a samo iznimno, u slučajevima kada se aktivira tzv. umbrella Clause ${ }^{20}$ odgovornost države je vezana za privatnopravni odnos, no i u tim slučajevima država je međunarodnim ugovorom (BIT-om ili multilateralnim) preuzela obvezu poštivanja svih preuzetih obveza u odnosu na investitore - pa tako i one koje proizlaze iz privatnopravnih ugovora zaključenih između države i investitora. ${ }^{21}$

17 Borzu Sabahi, Compensation and Restitution in Investor-State Arbitration Principles and Practice (OUP 2011) 61-86.

18 Balbir Sinh, 'Compensation Under International Investment Law Arbitration in Investor-State Infrastructure Contracts' (master thesis, Faculty od Law, University of Oslo 2017) <http://urn.nb.no/URN:NBN:no-63194> pristupljeno 19. srpnja 2021.

19 Riječ je o tvornici u Chorzówu, Germany v Poland, Case Concerning the Factory at Chorzów (Claim for Indemnity) (Jurisdiction) [1927] PCIJ Ser A No 9 (26 July 1927).

20 Kod aktivacije umbrella clause privatnopravne obveze države uzdižu se na međunarodnopravnu razinu zbog odredbe $\mathrm{u}$ međunarodnom ugovoru pa stoga obveza iz privatnopravnog odnosa i međunarodna obveza egzistiraju zajedno i investitor može voditi paralelne postupke koji će proizlaziti iz iste činjenične osnove, stranke u postupku bit će iste, no pravna osnova u jednom će postupku biti ugovor - dakle privatnopravna osnova, a u drugom međunarodni ugovor koji sadrži umbrella clause.

21 O pitanju nadležnosti tribunala da u arbitražnom postupku raspravlja zahtjev koji proizlazi iz umbrella clause - dakle zahtjev koji proizlazi iz ugovornog odnosa između države primateljice investicije i investitora vidjeti npr. u Jude Antony, 'Umbrella 
Umbrella clause se razvila iz potrebe da se zaštite imatelji koncesija za eksploataciju mineralnih sirovina. Začetnik ideje je Elihu Lauterpacht koji je savjetovao Anglo-iransku naftnu kompaniju (kasnije British Petroleum) u odnosu na rješavanje spora koji je proizašao iz nacionalizacije iranskih naftnih izvora. Naime, stav je naftnih kompanija bio, dakle stranih investitora, da zemlje izvoznice kapitala moraju osigurati za svoje investitore posebnu zaštitu njihovih ugovornih prava u odnosu na zemlju primateljicu investicije koja je ujedno i druga ugovorna strana. Lauterpach je predložio da se „osigura paralelna zaštita tako što će se ugovorna obveza koja proizlazi iz ugovora između investitora i Irana unijeti u međunarodni ugovor između Irana i Velike Britanije čime će se povreda ugovora ipso facto smatrati i povredom međunarodnog ugovora“. Umbrella clause svoju genezu ima u načelu pacta sunt servanda te je slična doktrini estoppel međunarodnog prava (ugovorna strana ne može isticati prigovor u odnosu na ono što je pristala ${ }^{22}$ ), ali ona ima i stabilizacijski učinak na regulatornu funkciju države s obzirom na to da se izmjenom propisa ne može dirati u ugovorna prava, osim ako bi bila riječ o višoj sili i izmijenjenim okolnostima (teoretičari navode da je suprotnost umbrella clause klauzula izmijenjenih okolnosti, tj. clausula rebus sic stantibus). ${ }^{23} \mathrm{U}$ odnosu na naknadu štete koju bi investitor potraživao po osnovi povrede ugovorne obveze i po osnovi povrede međunarodnog ugovora u paralelnim postupcima treba odmah naglasiti da bi se dosuđeni iznos naknade štete prebijao s onim koji se potražuje u drugom postupku.

Umbrella clause je prisutna u mnogobrojnim BIT-ovima, a bila je dio i prvog zaključenog BIT-a između Pakistana i Njemačke. Što se tiče multilateralnih ugovora, nema je u NAFTA-i, ali sadržana je u Ugovoru o energetskoj povelji. ${ }^{24}$

Navedeni instrumenti također propisuju standarde zaštite stranih investitora, a time i moguće povrede, pri čemu treba naglasiti da je iz dostupnih podataka vidljivo da investitori $\mathrm{u}$ tužbama najčešće ističu povredu Fair and Equitable Treatement ili skraćeno FET standarda (tzv. pravičan i jednak tretman), izravno ili neizravno izvlaštenje te povredu prava investitora donošenjem arbitrarnih, nerazumnih $\mathrm{i} / \mathrm{ili}$ diskriminatornih mjera kao jednog od vidova FET standarda. ${ }^{25}$

Materijalnopravna se zaštita prava stranih investitora očituje u vidu raznih obveza države primateljice investicije kao npr.: obveza države da u odnosu na stranog investitora postupa sukladno FET standardu - pošteno i pravično postupanje, pruža punu zaštitu i sigurnost stranim investitorima, ne provodi izvlaštenje imovine stranih investitora bez provođenja odgovarajućeg postupka i plaćanja tržišne naknade za izvlaštenu imovinu, postupa prema stranom investitoru jednako kao i prema domaćem - tzv. nacionalni tretman (national treatment), da

Clauses Since SGS V. Pakistan And SGS V. Philippines: A Developing Consensus' (2013) 29(4) Arbitration International 607. U tom se članku analiziraju dva arbitražna pravorijeka donesena u predmetima SGS v. Pakistan i SGS v. Philippines u kojima su tribunali došli do dijametralno suprotnih zaključaka u odnosu na nadležnost tribunala.

Više o doktrini estoppel u međunarodnom pravu vidjeti u npr. Louis de Gouyon Matignon, 'Estoppel in Public International Law' (Space Legal Issues, 19 June 2019) <www.spacelegalissues.com/estoppel-in-public-international-law/> pristupljeno 19. srpnja 2021. ili IC MacGibbon, 'Estoppel in International Law' (1958) 7(3) The International and Comparative Law Quarterly 468-513 <www.jstor.org/stable/755277> pristupljeno 19. srpnja 2021.

23 Anthony C Sinclair, 'The Origins Of The Umbrella Clause In The International Law Of Investment Protection' (2014) 20(4) Arbitration International.

25 Više o tipovima povreda i broju predmeta vidi na mrežnim stranicama UN-ove Komisije za trgovinu i razvoj: Investment Dispute Settlement Navigator (n 8). 
se na stranoga investitora primjenjuje najpovoljniji bilateralni sporazum koji je država primateljica investicije sklopila (tzv. MFN klauzula - Most Favourit Nation Clause) bez obzira na to što je povoljniji BIT sklopljen s drugom državom, obveze koja proizlazi iz umbrella clause itd.

Od navedenih ugovorenih materijalnopravnih zaštita dvije su posebno bitne, a to je zabrana povrede FET standarda i zabrana izvlaštenja bez provođenja odgovarajućeg postupka i plaćanja tržišne naknade pri čemu se FET standard u posljednjih 60 godina razvio do neslućenih razmjera i najčešće se navodi kao povreda u postupcima povodom tužbi stranih investitora protiv država zbog povrede BIT-a ili multilateralnog sporazuma u investicijskim arbitražama. ${ }^{26}$

FET standard se u BIT-ovima i multilateralnim ugovorima definira na način da ili:

- odredbe upućuju na "načela međunarodnog prava", na "međunarodno običajno pravo" ili na "minimalni standard postupanja" čime se definicija FET standarda povezuje s minimalnim standardom postupanja kako je definiran u predmetu F. H. Neer i Pauline Neer (SAD) c/a Meksiko ${ }^{27}$ ili

- $\quad$ ugovor sadrži vlastitu definiciju FET standarda ${ }^{28}$ ili

- $\quad$ FET standard nije kvalificiran, tj. ugovor i ne sadrži definiciju standarda i ne upućuje na međunarodno pravo pa je interpretacija ovoga standarda u slučaju spora u rukama tribunala te ovisi, kao i u ostalim slučajevima, o činjenicama u konkretnom predmetu.

FET standard sastoji se od nekoliko podstandarda, a to su:

- transparentno postupanje i osigurana stabilnost, uz posebno poštovanje legitimnih očekivanja investitora

- $\quad$ pravo na pošten i pravičan postupak pred sudovima i drugim tijelima (Denial of Justice)

- zabrana nerazumnih, diskriminatornih i arbitrarnih mjera prema stranim investitorima koje se mogu očitovati primjerice u pojedinačnim upravnim aktima ali i propisima

- $\quad$ postupanje u dobroj vjeri prema stranim investitorima. ${ }^{29}$

Kao što je vidljivo riječ je o standardu koji nije čvrsto definiran pa će i utvrđenje je li nastupila povreda FET standarda ovisiti o tome kako je sam standard definiran u BIT-u ili multilateralnom sporazumu koji predstavlja pravnu osnovu spora te činjenicama samoga spora. Pri tomu treba imati u vidu da, iako tribunali u međunarodnoj investicijskoj arbitraži nisu vezani odlukama tribunala u ranijim sličnim sporovima, arbitražni tribunali uporište za svoju odluku traže i u bogatoj praksi tribunala. Činjenica da tribunali nisu vezani odlukama ranijih tribunala (dakle da ne postoje presedani koji bi jamčili pravnu sigurnost) jedna je od glavnih kritika ovoga sustava. Naime, iako tribunali najčešće citiraju odluke u ranijim sličnim sporovima, činjenica da tribunali nisu vezani ranijim odlukama tribunala u sličnim sporovima ističe se kao jedan od glavnih nedostataka ovoga sustava jer ne pruža pravnu sigurnost s obzirom na to da stranke mogu samo pretpostaviti da će arbitar/arbitri slijediti pravni pristup izražen u ranijim odlukama.

26 Rudolf Dolzer and Christoph Schreuer, Principles of International Investment Law (2nd edn, OUP 2012) 130.

27 Tako CAFTA-DR u 10. poglavlju koje se odnosi na investitore veže FET standard uz minimalni standard postupanja sukladno međunarodnom, isto i NAFTA u članku 1105.

28 Tako članak 8.10 CETA-e (Comprehensive Economic Trade Agreement zaključen između EU-a i Kanade) sadrži vlastitu definiciju FET standarda (The Comprehensive and Economic Trade Agreement (CETA) <https://ec.europa.eu/trade/policy/in-focus/ceta/ ceta-chapter-by-chapter/> pristupljeno 19. srpnja 2021.) 
Uz FET standard, kao što je ranije spomenuto, posebno je značajno izvlaštenje. Glavna podjela u odnosu na razvijenu praksu arbitražnih pravila i same BIT-ove i multilateralne sporazume koji sadrže odredbe o zaštiti prava stranih investitora jest na:

- izravno izvlaštenje ${ }^{30}$

- neizravno izvlaštenje ${ }^{31}$ - to su mjere koje su jednake izvlaštenju, tj. čiji je učinak jednak izvlaštenju jer je investicija uništena - investitori upiru najčešće na administrativne, zakonodavne ili pravosudne akte države ili bilo kojeg drugog tijela čije djelovanje se može pripisati državi, s time da se povreda može sastojati i u propustu i u postupanju države. Pri tomu namjera države nije bitna za odgovornost. Upravo u situacijama u kojima investitori upiru na povredu zbog administrativnih, zakonodavnih ili pravosudnih akata države ili upravnog tijela najčešće se vidi i pozivanje na povredu podstandarda FET standarda kao što su povreda legitimnih očekivanja, nedostatak transparentnosti, zabranu diskriminatornih i arbitrarnih mjera. Na taj način investitori pokušavaju ostvariti zaštitu i u konačnici naknadu štete po dvije osnove kako bi dodatno osigurali uspjeh u sporu.

Većina BIT-ova i multilateralnih ugovora koji sadrže odredbe u odnosu na zaštitu stranih investitora sadrže odredbu o izvlaštenju s time da najčešće navode da je izvlaštenje dopušteno kada je u javnom interesu, kada je provedeno u odgovarajućem postupku te kada je za oduzetu imovinu plaćena tržišna naknada, a u dijelu koji se odnosi na neizravno izvlaštenje, najčešće ga samo spominju a da ga ne definiraju. Tribunali su se puno bavili izvlaštenjem i pitanjem definiranja neizravnog izvlaštenja, pitanjem je li izvlaštenje nezakonito ako samo nije plaćena naknada za izvlaštenu imovinu (ali proveden je odgovarajući postupak i utvrđenja je javna svrha) i to kako u odnosu na neizravno tako i izravno izvlaštenje. Dok bi se neplaćanje tržišne naknade za izvlaštenu imovinu kod izravnog izvlaštenja moglo podvesti pod povredu, u slučaju neizravnog izvlaštenja je to teže jer se tek odlukom tribunala određena mjera države proglašava izvlašćujućom pa je stoga i izračun štete kod neizravnog izvlaštenja drugačiji. Ovdje također treba naglasiti da je glavna razlika između neizravnog izvlaštenja i povrede FET standarda u tomu što je kod neizravnog izvlaštenja investicija postala bezvrijedna, dakle učinak je kao da je investicija bila predmet izravnoga izvlaštenja. U odnosu na neizravno izvlaštenje treba istaknuti da neće svaka državna mjera ili set mjera koja ima nepovoljan ekonomski učinak na investiciju predstavljati neizravno izvlaštenje. Kada propis ima legitimni cilj koji ima uporište u javnoj politici kao npr. u zaštiti okoliša, javnog zdravlja ili sigurnosti, nije diskriminatoran, u skladu je s načelom proporcionalnosti i donesen je u odgovarajućem postupku (u redovnom postupku, od nadležnog tijela i u javnoj raspravi), čak i ako ima negativan ekonomski efekt na investiciju neće predstavljati neizravno izvlaštenje. Ovaj zaključak proizlazi iz činjenice da svaka država ima zakonodavnu ovlast - ona ima pravo regulirati (tzv. Police Powers Doctrine).

U predmetu Suez c/a Argentina, tribunal je analizirao jesu li mjere koje je Argentina donijela tijekom ekonomske krize 2000-2002 neizravno izvlaštenje (u tom je dijelu tužba bila odbijena, ali utvrđena je povreda FET standarda) te je zaključio da se kod neizravnog izvlaštenja ponekad govori o tzv. „regulatornom oduzimanju“ u kojem država koristeći svoje pravo da

30 Više o izravnom izvlaštenju u npr. August Reinisch (ed), Standards of Investment Protection (OUP 2008) 171-204.

31 Više o neizravnom izvlaštenju u npr. Anne K Hoffmann, 'Indirect Expropriation' in Reinisch A (ed), Standards of Investment Protection (OUP 2008) 151-170. 
regulira, donosi mjere koje reduciraju vrijednost investicije, a da pri tomu ne oduzima imovinu investitora i ne oduzima kontrolu nad investicijom investitoru. ${ }^{32}$

U odnosu na vrste neizravnog izvlaštenja, šuljajuće izvlaštenje (creeping expropriation) tribunal je u predmetu Generation Ukraine v/a Ukrajina definirao kao izvlaštenje koje ima vremensku dimenziju jer se odnosi na situaciju u kojoj set postupanja koja se mogu pripisati državi tijekom određenog perioda dovode do izvlašćujućeg efekta na investiciji na način da ona postaje bezvrijedna ili da investitor gubi kontrolu nad investicijom. ${ }^{33}$

Investitori u arbitražnim postupcima najčešće upiru na povrede koje se podvode pod neizravno izvlaštenje.

\section{NAKNADA ŠTETE U MEĐUNARODNOJ INVESTICIJSKOJ ARBITRAŽI}

\section{VISINA ŠTETE - CHORZOW STANDARD}

Predmet Chorzow odnosi se na nezakonito oduzimanje tvornice nitrata izgrađene na njemačkom teritoriju 1915. godine, a koja je nakon I. svjetskoga rata, nakon što je Poljska stekla neovisnost, postala dio poljskoga teritorija. Unatoč činjenici da je dio teritorija na kojem se tvornica nalazila prešao u poljske ruke, tvornica je i dalje ostala u vlasništvu Njemačke na temelju Konvencije koja se odnosi na Gornju Šleska iz 1922. (tzv. Ženevska konvencija), a koja je ograničila suvereno pravo Poljske da oduzima imovinu njemačkih građana na području Gornje Šleske. Poljska je unatoč preuzetoj međunarodnoj obvezi prenijela vlasništvo tvornice na poljskoga državljanina zbog čega je Njemačka, u ime tvornice Chorzow, podignula tužbu protiv Poljske ${ }^{34}$ pred Stalnim sudom međunarodne pravde. Sud je u ovome predmetu posebno naglasio da postoji razlika između slučajeva kada je oduzimanje imovine zakonito, ali nije plaćena naknada, od slučajeva kao ovaj kada je oduzimanje imovine nezakonito pa je tužitelj stoga ovlašten zahtijevati restituciju. U ovom je slučaju sud zaključio da Poljska nije provela zakonito izvlaštenje te da je propustila platiti naknadu za izvlaštenu imovinu. Sud je također utvrdio da je Poljska oduzela imovinu koja ne može biti predmetom izvlaštenja pa stoga, čak i da je plaćena naknada za oduzetu imovinu, bila bi riječ o povredi međunarodnopravne obveze.

32 Expropriation: UNCTAD Series on Issues in International Investment Agreements II (United Nations 2012) <https://unctad.org/en/ Docs/unctaddiaeia2011d7_en.pdf> pristupljeno 19. srpnja 2021.

33 Generation Ukraine, Inc. v. Ukraine, ICSID Case No ARB/00/9 (16 September 2003) para 20.22.

34 U sporu vezano za Anglo-Iranian Oil Co. - trgovačkog društva registriranog u Velikoj Britaniji, Vlada Ujedinjene Kraljevine podnijela je, na temelju prava na diplomatsku zaštitu, tužbu Međunarodnim sudom pravde u ime Vlade Velike Britanije protiv carske iranske Vlade tražeći da carska iranska Vlada obešteti Anglo-Iranian Oil Co. Spor je proizašao iz sporazuma između carske perzijske Vlade i Anglo-Iranian Oil Co. kojim je kompanija dobila koncesiju za eksploataciju nafte, no koncesija joj je oduzeta jer su iranska Vlada i Senat 1951. godine donijeli zakon kojim je naftna industrija nacionalizirana. Sud se u ovom predmetu oglasio nenadležnim. Sud je zaključio da „ne može prihvatiti stav britanske Vlade da ugovor o koncesiji potpisan između iranske Vlade i Anglo-perzijske naftne kompanije ima dvostruki karakter“ jer „Vlada Velike Britanije nije stranka ugovora te ne postoji ugovor između iranske Vlade $i$ Vlade Velike Britanije“. Sud je zaključio da „ugovor o koncesiji ni na koji način ne regulira odnose dviju vlada pa stoga zahtjev Velike Britanije nije dopušten“. Kao što je vidljivo iz odluke mogućnost da država u ime svoga državljana ili trgovačkog društva podigne tužbu, ovom je odlukom odbačena. Anglo-Iranian Oil Co case (jurisdiction), judgment of July 22nd, I952: ICJ Reports I952 p 93. 
Sud je istaknuo da kada država nije ovlaštena izvlastiti imovinu stranca, stranac je ovlašten na restituciju (vraćanje u stanje kao da do povrede nije došlo), dok se kod zakonitoga izvlaštenja naknada limitira na vrijednost oduzete imovine u trenutku oduzimanja. Ako restitucija nije moguća, a najčešće nije, ona može biti zamijenjena naknadom štete, no u tom će slučaju država biti dužna platiti naknadu štete koja će tužitelja dovesti u stanje kao da do povrede nije ni došlo (dakle i svu izgubljenu dobit). ${ }^{35}$

Chorzow standard iz perspektive vještaka odgovara na tri temeljna pitanja. Od vještaka se očekuje da izračuna:

- tržišnu vrijednost izvlaštene imovine u trenutku izvlaštenja

- izmaklu dobit za razdoblje od trenutka izvlaštenja do datuma obeštećenja, tj. donošenja pravorijeka

- tržišnu vrijednost izvlaštene imovine u trenutku donošenja pravorijeka.

Slijedom navedenoga Chorzow standard nudi alternative:

- dosudu tržišne vrijednosti na dan izvlaštenja - vrijednost investicije u trenutku donošenja odluke (što može imati i negativne posljedice u slučaju inflacije)

- dosudu tržišne vrijednosti na dan donošenja odluke uvećane za izgubljenu dobit koju bi tužitelj ostvario u razdoblju od trenutka izvlaštenja do dana donošenja odluke. ${ }^{36}$

Ovaj standard je kodificiran u Nacrtu članaka o međunarodnoj odgovornosti država, posebno u članku 31. i 36. koji omogućavaju tužiteljima da, u slučajevima kada je utvrđena povreda međunarodnoga prava od strane tužene države, zahtijevaju restituciju i daljnju štetu koja se ne može otkloniti vraćanjem oduzete imovine. Smisao standarda Chorzow, a i Nacrta članaka, jest u tome da u slučaju kada država povredom međunarodnoga prava počini povredu prava stranca, reparacija štete u cijelosti izbriše posljedice povrede (to je razlog zašto strani investitori u pojedinim slučajevima traže i tzv. moralnu štetu, tj. neimovinsku štetu).

Treba imati u vidu da instrumenti koji propisuju materijalnopravnu zaštitu stranih investitora (posebno BIT-ovi i multilateralni međunarodni ugovori) najčešće sadrže odredbu kojom se uređuje što je izvlaštenje kao i visinu naknade u slučaju zakonitoga izvlaštenja. Ti instrumenti najčešće definiraju izvlaštenje kao oduzimanje imovine u javne svrhe, u skladu s pravilima postupka, na nediskriminatoran način i uz plaćanje naknade za izvlaštenu imovinu s time da obično propisuju da se u slučaju zakonitoga izvlaštenja ima platiti pravedna naknada ili da se ima promptno platiti adekvatna i efikasna naknada (tzv. Hullova formula nazvana prema američkom državnom tajniku Cordellu Hullu koji ju je osmislio), odnosno tržišna naknada. Valja naglasiti da su pojedini tribunali ocijenili činjenicu da je država propustila platiti naknadu za oduzetu imovinu kod inače zakonitoga izvlaštenja kao presudnom pa su stoga odlučili da je zbog te činjenice i izvlaštenje bilo nezakonito. U slučaju utvrđenja da je izvlaštenje bilo zakonito tužitelj bi bio ovlašten na jednu od navedenih naknada i to one utvrđene $u$ vrijeme oduzimanja (ex ante).

Za razliku od zakonitoga izvlaštenja, kod nezakonitoga izvlaštenja ili kod povrede kojega drugog prava investitora (kao npr. kod povrede FET standarda ili kod povrede prava inve-

35 John A Trenor, The Guide to Damages in International Arbitration (2nd edn, Law Business Research 2017).

36 Manuel A Abadala, 'Chorzow's Standard Rejuvenated: Assessing Damages in Investment Treaty Arbitration' (2008) 25(1) Journal of International Arbitration 103. 
stitora donošenjem arbitrarnih, nerazumnih i/ili diskriminatornih mjera) tužitelj je ovlašten zahtijevati potpunu reparaciju koja će se sastojati u restituciji (ili naknadi štete, prema odabiru tužitelja) i dodatnoj šteti prema vrijednosti u trenutku donošenja arbitražnoga pravorijeka (ex post) jer će samo na taj način tužitelj biti stavljen u poziciju kao da do povrede nije došlo. Unatoč navedenomu, datum evaluacije štete (ex ante - u vrijeme počinjenja povrede i ex post - u vrijeme donošenja arbitražnoga pravorijeka) treba pozorno sagledavati jer je moguće da datum, ovisno i o odabranoj metodi, utječe ne samo na visinu štete, nego i da dovede do nepravednoga rezultata. Pojedini tribunali su stoga kao datum nastanka štete uzimali onaj koji je bio povoljniji za tužitelja navodeći da bi svaki drugi pristup bio nepravedan - tako npr. arbitar pojedinac Dupuy u predmetu Texaco Overseas Petroleum Company c/a Vlada Arapske Republike Libije citira stav bivšega predsjednika Međunarodnoga suda pravde Jiméneza de Aréchagae koji je, među ostalim, zastupao stav da naknada štete mora što više sličiti restituciji pa je stoga i datum na koji pada obveza naknade štete kriterij u utvrđivanju visine naknade štete. ${ }^{37}$ Konačno, kod povreda kao što su neizravno izvlaštenje ili povreda FET standarda gdje skup mjera ili postupaka države dovode do povrede, iznimno je teško utvrditi datum kada je povreda nastupila pa se može reći da u tim slučajevima tribunali taj datum određuju arbitrarno, posebno imajući u vidu izneseni stav u predmetu Texaco Overseas Petroleum Company da je datum nastanka štete ujedno i kriterij za utvrđivanje njezine visine.

Pitanje trenutka od kojega će se računati šteta kao i načina izračuna štete posebno je problematiziran u predmetu $A D C$ c/a Mađarska. ${ }^{38} \mathrm{I}$ u tom je predmetu tribunal datum od kojega se računa naknada štete tretirao kao kriterij za utvrđivanje visine naknade štete. Činjenice u predmetu su kako slijedi. Aerodrom blizu Budimpešte imao je putničku i vojnu funkciju. Aerodrom se 1992. godine sastojao od dva terminala, bio je u vlasništvu države, a 1992. godine SAD i Mađarska zaključuju da je potrebno izgraditi novi terminal. Aerodromom je upravljala državna agencija ATAA koja je raspisala javni natječaj za gradnju novoga terminala. Postupak se trebao provesti u tri faze u kojem se imao odabrati partner za obnovu jednog terminala i idejno rješenje i gradnju novoga terminala kao i financiranje, gradnju i upravljanje popratnim sadržajima. ADC je pobijedio na natječaju, a ATAA je na temelju rezultata natječaja 1995. godine zaključila s ADC-om glavni ugovor. Gradnja terminala 2B dovršena je 1998. godine (na vrijeme) te je terminal otvoren i predan mađarskoj Vladi. ADC upravljao je i iznajmljivao popratne prostore do kraja 2001. godine kada mu je naloženo da isprazni prostore jer je zbog izmjena zakona ATAA ukinuta, a njezin sljednik, mađarsko trgovačko društvo JS Co. (u vlasništvu Mađarske) od 1. siječnja 2002. više nije bilo ovlašteno prepustiti upravljanje i iznajmljivanje popratnih prostora trećim osobama pa su stoga ugovori koji su proizašli iz glavnoga ugovora, a prema kojima je ADC ovlašten upravljati i iznajmljivati popratne prostore na Terminalu 2A i 2B aerodroma, prestali postojati jer su sadržavali činidbu koju nije moguće izvršiti. Otad je prestalo i plaćanje dividende na koju je ADC dotad bio ovlašten. Aerodrom je privatiziran 2005. godine na način da je BAA (trgovačko društvo iz Velike Britanije) platilo 2.23 milijarde američkih dolara za 75\% minus jedna dionica udjela u aerodromu.

37 Robert B von Mehren, 'International Arbitral Tribunal: Award on the Merits in Dispute Between Texaco Overseas Petroleum Company/California Asiatic Oil Company and the Government of the Libyan Arab Republic (Compensation for Nationalized Property)' (1978) 17(1) International Legal Materials 33-34 <www.jstor.org/stable/20691828?read-now=1\&seq=3\#page_scan_ tab_contents> pristupljeno 19. srpnja 2021. 
U tom je predmetu tribunal u odnosu na meritum utvrdio da je država povrijedila BIT izravno izvlastivši tužitelja. Tribunal je ne samo u cijelosti primijenio i tako rehabilitirao Chorzow standard, već je i naglasio da povreda BIT-a dovodi do aktivacije međunarodnoga običajnog prava te određivanja naknade štete sukladno međunarodnomu običajnom pravu pa je stoga datum otkad se računa naknada štete datum donošenja arbitražnoga pravorijeka (dakle i u ovom je predmetu datum donošenja pravorijeka bio kriterij određivanja visine naknade štete). Tribunal je odredio kao datum naknade štete 30. rujna 2006., tj. datum donošenja arbitražnoga pravorijeka te je utvrdio da tužitelj ima pravo na potpunu reparaciju štete i to računano na dan donošenja pravorijeka. To konkretno znači da je tribunal prihvatio DCF metodu izračuna štete koja, uz stvarnu štetu (regulirana u definiciji izvlaštenja u BIT-u koji je Mađarska povrijedila tržišna vrijednost investicije u trenutku izvlaštenja), uključuje i izmaklu dobit tužitelja koju bi investitor ostvario do trenutka donošenja pravorijeka da nije bilo (nezakonitoga) izvlaštenja. U odnosu na datum koji se ima uzeti kao datum za određivanje visine naknade štete posebno su zanimljive točke 496. i 497. pravorijeka u kojima tribunal navodi: “Ovaj je predmet gotovo pa jedinstven između predmeta u kojima se odlučivalo vezano za izvlaštenje imovine u vlasništvu stranca jer je vrijednost investicije nakon datuma izvlaštenja (1. siječnja 2002. godine) značajno narasla dok je u ostalim predmetima u kojima su arbitri primjenjivali Chorzow standard vrijednost investicije pala nakon miješanja države kroz zakonodavnu aktivnost. Upravo je i to bio razlog zašto su tribunali koji su primjenjivali Chorzow standard kao datum dospijeća naknade štete odredili datum izvlaštenja. Međutim, u ovom konkretnom predmetu koji je predmet sui generis primjena Chorzowa standarda podrazumijeva primjenu datuma donošenja arbitražnog pravorijeka kao datuma nastanka štete, a ne datuma kada je došlo do izvlaštenja jer je nužno tužitelja staviti u poziciju u kojoj bi bio da nije bilo izvlaštenja."

Kao što je vidljivo iz navedenoga predmeta, tribunal je vrijeme koje će uzeti kao relevantno za naknadu štete prilagodio kako bi u cijelosti reparirao nastalu štetu na način da je izračun štete vezao uz dan donošenja pravorijeka (30. rujna 2006.), a ne trenutak izvlaštenja tj. nastanka štete (što bi bio 1. siječnja 2002.).

Pa ipak, treba imati u vidu da Chorzow standard zahtijeva usporedbu stvarne situacije s hipotetskom budućnošću pa stoga u mnogim slučajevima ne pruža dostatno siguran rezultat i postaje posebno špekulativan kada se projekcija odnosi na dalju budućnost koja se eventualno mogla ostvariti da nije došlo do povrede. ${ }^{39}$

\section{OMJER UTUŽENE I DOSUĐENE NAKNADE ŠTETE - STATISTIČKI PODATCI}

Statistička obrada podataka o predmetima dostupnima na mrežnim stranicama UNCTAD-a ${ }^{40}$ kao i studije PwC-a iz 2015. ${ }^{41}$ i iz 2017. ${ }^{42}$ godine upućuje na veliko razilaženje izme-

39 Thomas W Wälde and Borzu Sabahi, 'Compensation, Damages, and Valuation' in Muchlinski P, Ortino F and Schreuer C (eds), The Oxford Handbook of International Investment Law (OUP 2008) 1057.

40 Investment Dispute Settlement Navigator (n 8).

41 International Arbitration damages research - 2015 (PwC, 2015) <www.pwc.co.uk/forensic-services/disputes/insights/assets/ pdf/2015-international-arbitation-damages-research.pdf> pristupljeno 19. srpnja 2021.

42 International Arbitration damages research - 2017 update (PwC, 2017) <www.pwc.co.uk/forensic-services/assets/ pwcinternational-arbitration-damages-research-2017.pdf> pristupljeno 19. srpnja 2021. 
đu vještačkih nalaza pripremljenih za potrebe tužitelja i potrebe tuženika te na činjenicu da tužitelji redovito previsoko postavljaju tužbeni zahtjev.

Studija PwC-a iz 2015. godine ${ }^{43}$ u kojoj je analizirano 95 arbitražnih pravorijeka utvrdila je da su vještaci tuženih država dolazili do u prosjeku $13 \%$ izračuna vještaka tužitelja, dok su tribunali u prosjeku dosuđivali 37\% utuženoga iznosa. Dodatna studija koju je PwC proveo 2017. godine $^{44}$ i u kojoj je analiziran 21 novi arbitražni pravorijek pokazala je da kada se uključe i novi rezultati u studiju iz 2015. godine, visina dosuđene štete u odnosu na utuženu (i izvještačenu) iznosi $36 \%$ dok su vještaci za tužene države u prosjeku izračunavali $12 \%$ vrijednosti utužene štete.

Za potrebe ovoga rada analizirani su podatci o investicijskim arbitražama i ishodu spora u odnosu na visinu dosuđene štete dostupni na mrežnim stranicama UNCTAD-a (Investment Policy Hub). Naime, UNCTAD na mrežnim stranicama evidentira sve poznate investicijske arbitraže od njihove pojave. Prikaz podataka redovno se osvježava te su na stranicama evidentirana i obrađena 1104 slučaja (zaključno s 31. prosincem 2020.). Evidencija uključuje imena stranaka, linkove na mrežne stranice gdje se mogu naći dodatne informacije o konkretnom predmetu, kratak prikaz spora, imena arbitara, sektor iz kojeg spor proizlazi (primarni, sekundarni i tercijarni sektor), ishod spora kao i traženu i dosuđenu odnosno nagođenu naknadu štete kada je to poznato, ishod spora, podatke o pobijanju arbitražnog pravorijeka itd. ${ }^{45} \mathrm{Za}$ potrebe ovoga rada obrada podataka dostupnih na mrežnim stranicama UNCTAD-a je, od 356 odluka u kojima je prihvaćen tužbeni zahtjev ili je spor završio nagodbom, uključila sve predmete u kojima je poznat utuženi i dosuđeni iznos. Slijedom navedenoga statistička analiza obuhvaća 220 predmeta koji su analizirani i prikazani u donjim grafovima prema sektoru iz kojega proizlazi spor, a s obzirom na utuženu i dosuđenu ili nagođenu visinu štete. ${ }^{46}$

Provedena analiza pokazuje da tribunali u prosjeku dosuđuju 37\% utuženoga iznosa (Graf 3) s time da su najviši zahtjevi kao i najviši iznosi dosuđene naknade štete grupirani u primarni sektor - eksploataciju mineralnih sirovina, nafte i plina (Graf 5). To ne iznenađuje jer je riječ o najlukrativnijim poslovima i poslovima koji najčešće proizlaze iz ugovora o koncesiji koji dugoročno uređuju odnos između investitora i države. Ta činjenica može biti iznimno bitna (kao što će se uostalom i vidjeti u daljnjem tekstu) za izračun visine štete jer naknada štete u takvim predmetima obuhvaća (katkad neopravdano) i izmaklu buduću dobit. Zbog navedenih činjenica je i konačni postotak dosuđene štete u primarnom sektoru visokih 37 \% i taj postotak zbog visine vrijednosti predmeta spora značajno utječe i na konačni rezultat (udio primarnog sektora u odnosu na ukupno dosuđeni iznos je 79\%). U sekundarnom je sektoru koji se odnosi na proizvodnju (npr. hrane, električne energije itd.) taj postotak nešto niži i iznosi 32\% (Graf 7). U području tercijarnoga sektora tribunali su u prosjeku također dosuđivali $35 \%$ utužene visine štete (Graf 8$).{ }^{47}$

43 International Arbitration damages research - 2015 (n 41).

44 International Arbitration damages research - 2017 update (n 42).

45 O metodologiji prikupljanja i obrade podataka vidjeti više na:<https://investmentpolicy.unctad.org/pages/1057/isds-navigatorabout-and-methodology> pristupljeno 19. srpnja 2021.

46 Podatci su dobiveni analizom podataka dostupnih na mrežnim stranicama UN-ove Komisije za trgovinu i razvoj: Investment Dispute Settlement Navigator (n 8). 
Treba naglasiti da, iako je Republika Hrvatska s obzirom na svoju veličinu i broj stranih investicija često tužena zbog povreda prava stranih investitora (19 predmeta ${ }^{48}$ ) koja proizlaze iz bilateralnih i multilateralnih međunarodnih ugovora, u odnosu na predmet ovoga rada statistički nije zanimljiva. Naime, od svih investicijskih arbitraža koje su se vodile protiv Republike Hrvatske i koje su zaključene, dakle poznat je ishod spora, jedino je za potrebe ovoga rada zanimljiva ona koju je pokrenuo austrijski državljanin Georg Gavrilović i Gavrilović d.o.o. pri ICSID-u (ICSID-ov predmet br. ARB/12/3949) jer je u tom predmetu Hrvatskoj naloženo plaćanje naknade štete. Taj je predmet uključen u donju analizu, ali s obzirom na činjenicu da je riječ o predmetu iz sekundarnog sektora, sama činjenica da je u tom predmetu dosuđeno tek manje od $2 \%$ utuženog iznosa ne utječe na konačni rezultat jer su vrijednosti predmeta spora mnogo više $u$ investicijskim arbitražama proizašlim iz primarnog sektora. Nadalje, ovaj predmet nije od posebnog značaja za analizu teme ovoga članka jer je u ovom predmetu tribunal utvrdio da je Republika Hrvatska izvlastila investitora pa je i sama formula za izračun štete proizašla iz austrijsko-hrvatskog BIT-a. Situacija bi bila puno drugačija da je tribunal utvrdio i povredu FET standarda jer bi u tom slučaju izračun visine štete uključivao i izmaklu dobit. U tom bi slučaju taj predmet bio zanimljiv i s aspekta utjecaja rizika na izračun visine štete jer je investicija bila obuhvaćena ratnim zbivanjima tijekom Domovinskog rata pa bi bilo zanimljivo vidjeti koliko bi ta činjenica utjecala na konačni izračun visine štete.

Graf 3, 4 i 5 razrada su analiziranih predmeta po utuženoj šteti i dosuđenoj šteti, udjelu pojedinog sektora u 220 analiziranih predmeta te udjelu dosuđene štete po sektoru u ukupno dosuđenoj šteti.

Graf 3: Zbirni prikaz omjera utužene štete i dosuđene štete - uključuje sve sektore (tribunali su u prosjeku dosudili $37 \%$ utuženoga iznosa) ${ }^{50}$

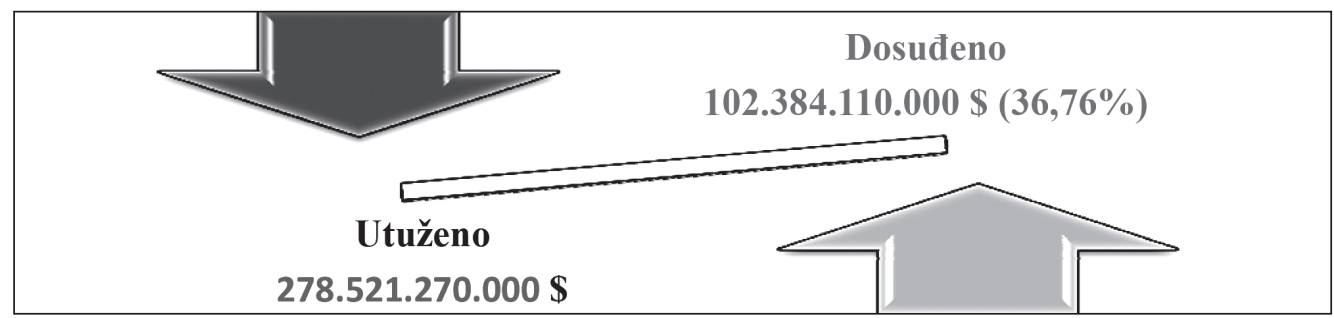

Graf 4 prikazuje udio pojedinog sektora u broju analiziranih predmeta dok Graf 5 prikazuje udio pojedinog sektora u ukupno dosuđenoj šteti u analiziranih 220 predmeta.

48 Vidi više o predmetima na: <https://investmentpolicy.unctad.org/investment-dispute-settlement/country/51/croatia/ respondent> pristupljeno 19. srpnja 2021.

49 Georg Gavrilovic and Gavrilovic doo v Republic of Croatia, ICSID Case No ARB/12/39 (26 July 2018). 


\section{Graf 4}

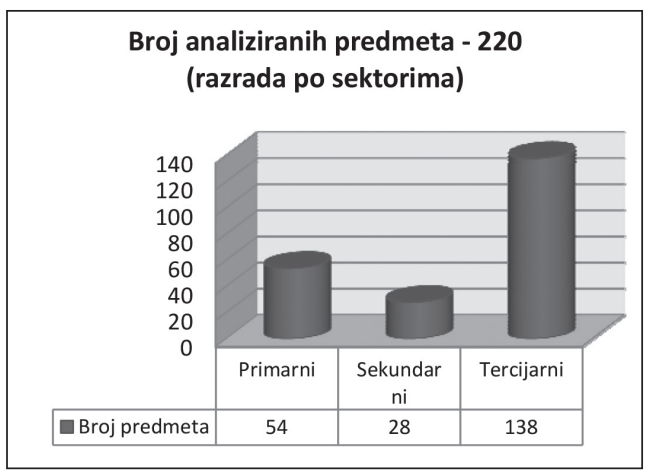

Graf 6: Prikaz omjera utužene štete i dosuđene štete u primarnom sektoru (eksploatacija nafte, plina i ruda te poljoprivreda, šumarstvo i ribarstvo) - tribunali su u prosjeku dosudili $37 \%$ utuženoga iznosa

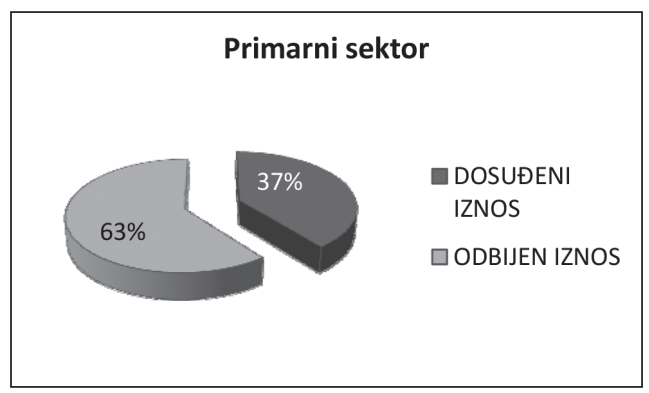

Graf 5

\section{Udio u ukupno dosuđenoj šteti za sve sektore}

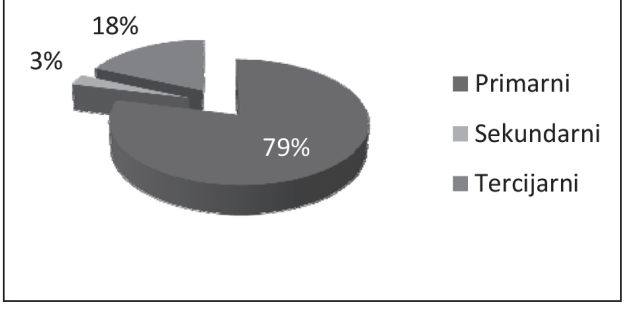

Graf 7: Prikaz omjera utužene štete i dosuđene štete u sekundarnom sektoru - tribunali su u prosjeku dosudili $32 \%$ utuženoga iznosa

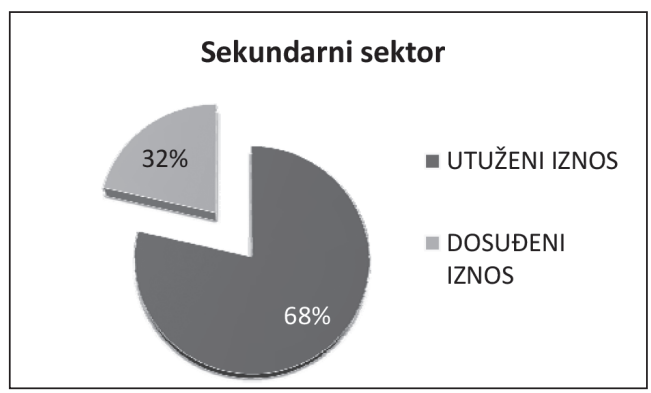

Graf 8: Prikaz omjera utužene štete i dosuđene štete u tercijarnom sektoru (usluge) Tribunali su u prosjeku dosudili $35 \%$ utuženoga iznosa ${ }^{53}$

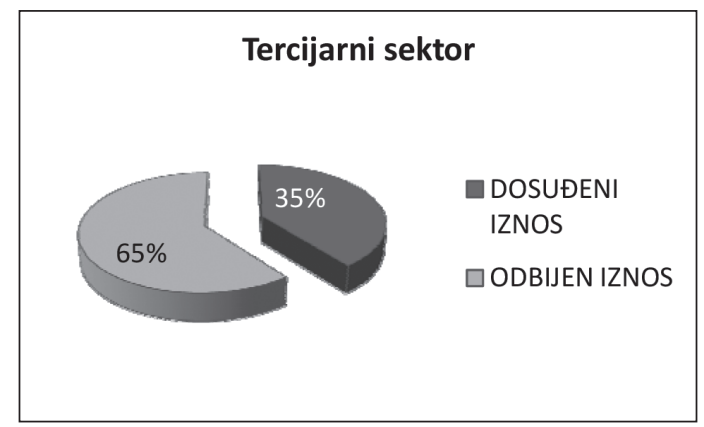

51 Podaci su dobiveni analizom podataka dostupnih na mrežnim stranicama UN-ove Komisije za trgovinu i razvoj: <https:// investmentpolicy.unctad.org/investment-dispute-settlement/advanced-search> pristupljeno 19. srpnja 2021. 
Zanimljivo je da se prema podatcima UNCTAD-a 138 slučajeva (od analiziranih 220) odnose na tercijarni sektor u kojem su tužitelji utužili više od 51 milijarde američkih dolara, a dosuđeno im je nešto više od 18 milijardi dolara što u konačnici čini 35\% utuženoga iznosa. Taj podatak ne iznenađuje jer je riječ o sektoru usluga koji se najčešće odnosi na pružanje financijskih usluga, usluga vodovoda, odvodnje i zbrinjavanja otpadnih voda, usluga iz područja energetike i usluge izgradnje. Sve su te investicije u trenutku utuženja već značajno, ako ne i u cijelosti, razvijene pa je i izračun naknade štete točniji i prihvatljiviji nego u slučajevima kada je investicija tek u razvoju i kada mnogi faktori rizika utječu ne samo na njezin razvoj, nego i očekivanu dobit. Ne iznenađuje, također, ni ukupni rezultat u odnosu na visinu utuženoga i dosuđenoga iznosa jer su najviši tužbeni zahtjevi u primarnom sektoru (54 predmeta) koji se odnosi na eksploataciju mineralnih sirovina, nafte i plina. Zanimljivo je da je u 28 predmeta koji proizlaze iz sekundarnih djelatnosti (djelatnosti proizvodnje) ukupan dosuđeni iznos najniži - 32\% od utuženoga iznosa, no kada se uzme u obzir činjenica da je u osam predmeta riječ o državama Srednje i Južne Amerike (u pet predmeta tužena je Venezuela), kao i činjenicu da je mahom riječ o predmetima u kojima je tužba podnesena protiv zemlje u razvoju, rizik države, tj. rizik koji postoji u odnosu na gospodarsku i političku stabilnost zemlje zasigurno utječe i na izračun visine štete, posebice u dijelu koji se odnosi na očekivanu izgubljenu dobit.

Kao što je već spomenuto odabir metode izračuna visine štete, uz zadatak koji se postavlja vještaku te datum otkad se računa šteta - izravno utječu na izračun visine pa će se u nastavku dati osvrt na glavne metode izračuna štete i odnos tribunala prema odabranim metodologijama izračuna.

\section{METODE IZRAČUNA ŠTETE}

\section{UVODNA RAZMATRANJA}

Međunarodno običajno pravo ne sadrži odredbe o metodi izračuna štete te je ona u konačnici ostavljena tribunalima koji odlučuju u konkretnom predmetu. Pri tomu je uloga financijskih vještaka ključna jer će visina štete u slučaju ovisiti o metodi izračuna štete, ali i sposobnosti vještaka da u unakrsnom ispitivanju uvjeri tribunal u točnost izračuna. Problem za vještake (osim izbora metode) predstavlja zadatak koji određuje stranka koja angažira vještaka, čime utječe i na pravnu kvalifikaciju navodne povrede (pa tako tužena država može tvrditi da je izvlaštenje bilo zakonito, a tužitelj da je bilo nezakonito što dovodi do značajne razlike u izračunu visine štete), kao i dokumentacija na temelju koje vještak izrađuje vještački nalaz. Pa ipak, odluka je o visini štete na tribunalu pa arbitri (a i odvjetnici koji zastupaju u arbitražnim postupcima) moraju uložiti dodatni napor kako bi se upoznali s metodama izračuna štete, rizicima koji oni nose te u konačnici donijeli pravilnu odluku. U nastavku se daje prvo nekoliko primjedbi u odnosu na naknadu štete kao vrste reparacije radi povrede međunarodnog prava, a nakon toga pregled metoda izračuna naknade štete u odnosu na utvrđenu vrstu povrede. 
Funkcija reparacije štete sastoji se od obeštećenju, ali i sprečavanju neopravdanoga obogaćenja onoga koji je počinio povredu. ${ }^{54}$

Pri tomu treba imati u vidu da se reparacija sastoji od restitucije, plaćanja kompenzacije - naknade štete i satisfakcije, dakle tri modaliteta, pa stoga ponekad samo plaćanje naknade štete nije i najbolji modalitet reparacije.

Unatoč tomu praksa je pokazala da plaćanje naknade štete najmanje dira u suverenitet države i njezino pravo da izvršava svoju javnopravnu funkciju što se reflektira i u čl. 35 . Nacrta članaka o međunarodnopravnoj odgovornosti država koji počinje s obvezom restitucije, ali onda, u slučaju nemogućnosti restitucije, prelazi na proporcionalno plaćanje naknade štete. Najnoviji trendovi u međunarodnim ugovorima, a i sam sustav rješavanja sporova unutar Svjetske trgovinske organizacije (WTO) pokazuju da plaćanje naknade štete nije najefikasniji način vezano za međunarodnu disciplinu pojedine države. Upravo praksa WTO-a, kao i praksa upravnih sudova pokazuje da je plaćanje naknade štete (kompenzacije za počinjenu povredu) tek na drugom mjestu dok kao sankcija za povredu prevladava nalog državnom tijelu da ispravi povredu. Slično se uočava u Europskom pravu u kojem je uobičajeno u slučaju povrede Europskoga prava naložiti ukidanje vladine mjere (propisa) ili nalaganje poduzimanja mjera, a ne plaćanje naknade štete. Stav da ozbiljne povrede kao npr. uskrata pravde (denial of justice), ali i drugi elementi FET standarda i zabrane diskriminiranja stranih investitora u odnosu na domaće mora biti popraćena izdašnom financijskom kompenzacijom - više pripadaju u vrijeme nacionalnih država 19. stoljeća nego u današnje moderno vrijeme globalnoga tržišta. Naime, ako analiziramo javno pravo modernih država kao i međunarodno pravo u području zaštite ljudskih prava koje je najsličnije investicijskoj arbitraži primijetit ćemo da je primarni odgovor na povredu da se povreda otkloni, tj. donese određena mjera, ali ovaj put zakonita. Nema razloga da se takav fleksibilan pristup ne preuzme i u investicijskoj arbitraži te da se čl. 35. Nacrta članaka o međunarodnopravnoj odgovornosti država čita na način da se reparacija štete može sastojati od više elemenata, npr. kombinacije restitucije i naknade štete. Upravo to je bio pristup tribunala u predmetu Goetz c/a Burundi $i^{55}$ u kojem je tribunal prvo donio odluku kojom je utvrdio odgovornost države za povredu međunarodnoga prava neizravnim izvlaštenjem, dok je odluku o načinu obeštećenja odgodio davši strankama mogućnost da se dogovore o modalitetu obeštećenja što je rezultiralo time da je Burundi izdao novu dopusnicu za slobodnu zonu, što je bilo najbliže punoj restituciji te platio dogovorenu naknadu štete - kompenzaciju za počinjenu povredu. ${ }^{56}$

Pa ipak, pravilno ukazuju van Houtte i MsAsy da međunarodni ugovori za zaštitu investicija prvenstveno predviđaju novčanu naknadu za povredu te je upitno kako bi se u ovršnom postupku državi naložilo (državu natjeralo) da povuče ili ukine spornu regulatornu mjeru koja je dovela do povrede međunarodnoga prava. Osim toga, i sama Washingtonska tj. ICSID konvencija u članku 54. implicira da je moguća ovrha samo određene naknade štete - dakle novčano obeštećenje iz čega bi se također moglo postaviti pitanje jesu li tribunali u arbitražnim postupcima prema ICSID konvenciji i arbitražnim pravilima uopće ovlašteni odrediti reparaciju štete koja nije novčana. ${ }^{57}$

\footnotetext{
54 Wälde (n 39) 1054.

55 Antoine Goetz and others v. Republic of Burundi, ICSID Case No ARB/95/3 (10 February 1999).

56 Wälde (n 39) 1060-1064.

57 Hans van Houtte and Bridie McAsey, 'Future Damages in Investment Arbitration: A Tribunal with a Crystal Ball?' in Caron DD and others (eds), Practising Virtue: Inside International Arbitration (OUP 2016) 642-643.
} 
Prije prelaska na pojedine metode izračuna naknade štete potrebno je upozoriti na još jedan detalj u odnosu na naknadu štete, a to je dihotomija naknade stvarne štete i izgubljene dobiti (damnum emergens/lucrum cesans). U odnosu na izvlaštenje treba naglasiti da plaćanje buduće izgubljene dobiti može biti sporno jer bilateralni i multilateralni međunarodni ugovori predviđaju plaćanje tržišne naknade za izvlaštenu imovinu (prema Hullovoj formuli i to korištenjem metode tržišnog pristupa tj. market approach ili going concerne).

\section{GLAVNE METODE IZRAČUNA}

1.) Pristup na temelju prihoda ili trenutačna neto vrijednost budućega priljeva, tj. NPV DCF metoda (Net Present Value of Discontinued Cash Flow) - ovaj izračun uz izračun stvarne štete anticipira izmaklu dobit prema neto vrijednosti u trenutku koji je određen kao datum od kojega se računa nastup štetnoga događaja. Ovo je trenutačno dominantna metoda koju posebno preferiraju investitori, a ona u svojoj biti kao nepobitnu činjenicu uzima da sadašnji prihod vrijedi više od mogućeg prihoda u budućnosti. Ova metoda prema nekim autorima nije ništa drugo nego „špekulacija o budućnosti obučena u matematičke formule“. Manipuliranje inicijalnim brzim rastom koji se jednostavno preslikava na budućnost, a da se ne uzima u obzir konkurencija, mogući rizici kao što su veće porezno opterećenje ili zakonodavne izmjene, dovode do rezultata koji je investitorima privlačan, ali nije i objektivan. Pokojni Tom Stauffer tvrdio je da napuhana knjigovodstvena vrijednost, tržišna vrijednost kao i NPV/DCF metoda zahtijevaju da arbitri detektiraju i razumiju razliku u varijablama koje zagovaraju tužiteljev i tuženikov vještak i to posebno u odnosu na konačni rezultat. U tome im mogu pomoći i vještaci koje imenuje sam tribunal. Pri tomu najbitnije je znati postaviti prava pitanja kako bi se utvrdila primjerenost $\mathrm{i}$ točnost pojedine metode. NPV/DCF metoda primjerena je kada se temelji na 5 - 10 godina podataka o prihodima koji se onda koriste za predviđanje budućih neto prihoda s time da se ne može koristiti za izračune koji se temelje na pretpostavkama kao što su da će doći do produljenja postojećega ugovora ili sklapanja novoga, osim kada je to vrlo vjerojatno pa time i dokazivo, kako bi se što više uklonila spekulativnost ove metode. ${ }^{58}$

Ova metoda nije prikladna za projekte koji su ostali tek u začetku i nisu se razvili jer nema podataka o ranijim prihodima pa će za te projekte biti povoljnije dolje naznačene metode.

2.) Knjigovodstvena metoda i povezane metode koje se baziraju na historijskim troškovima i informacijama o dobiti (historijski troškovi/troškovi investicije) - ova metodologija određuje naknadu štete na temelju stvarno uloženih sredstava, novčanoga tijeka i troškova investicije te je druga najčešće prihvaćena metoda izračuna štete prema analizi PwC-a iz 2015. (korištena je u 33 predmeta). ${ }^{59}$ Ovo je i metoda koju tribunali najčešće prihvaćaju u odnosu na to koliko često se predlaže, a posebno se koristi kada bi izračun štete po DCF metodi bio špekulativan.

S obzirom na to da se ova metoda temelji na knjigovodstvenim podacima ovo je i najobjektivnija metoda, međutim slabost joj je da ne uzima u obzir trendove tržišta kapitala, koliko će određena imovina u budućnosti stvoriti nove vrijednosti, pa stoga nije dobra za obeštećenje

58 Wälde (n 39) 1074-1077.

59 International Arbitration damages research - 2015 (n 41). 
investitora koji je zbog povrede izgubio ugovor. Pa ipak, i sam savjesni investitor oslanja se pri planiranju investicije na historijske troškove, $\mathrm{tj}$. podatke te stoga nema razloga ne primijeniti Buffet/Grahamovu metodu kao podmetodu koja upravo uzima u obzir historijske podatke i to posebno prošlu dobit, tj. zaradu. ${ }^{60}$

3.) Tržišni pristup (tzv. market approach ili going concerne) uzima u obzir vrijednost sličnih investicija te se bazira na komparativnoj analizi. Vještak prilagođava izračun naknade štete sukladno vremenu izračuna, promjenama u ekonomiji, industriji i gospodarstvu, a ako nema dovoljno informacija o tome koliko je rizik zemlje utjecao na procjenu štete, odgovarajuća prilagodba možda neće biti moguća. Ova se metoda prema analizi PwC-a iz 2015. ne koristi često, ali vještaci ju često koriste kako bi dodatno provjerili DCF metodu. Tribunali ju najčešće prihvaćaju kada se DCF metoda smatra spekulativnom i prerizičnom.

\section{ODABIR METODA IZRAČUNA NAKNADE ŠTETE - ANALIZA}

Istraživanje kompanije Pricewaterhousecoopers $(\mathrm{PwC})$ iz $2015 .{ }^{61}$ pokazuje da je DCF metoda najčešće korištena metoda. DCF metoda bila je predložena u 59 od 95 analiziranih predmeta $(68 \%$ slučajeva), a tribunali su ju prihvatili kao metodu izračuna štete u 37 predmeta (38\% slučajeva). Tribunali ju katkad odbijaju jer ju u konkretnom predmetu smatraju neprimjenjivom budući da nema dovoljno dokaza za izračun izmakle dobiti s obzirom na to da je investicija u ranoj fazi razvoja pa bi izračuni bili špekulativne naravi. S druge strane ova metoda je prihvatljiva kada je riječ o investiciji na razvijenom tržištu na kojem postoji dovoljno parametara da se izračuna i šteta u vidu izmakle dobiti za novi poduzetnički pothvat, tj. investiciju. Pri tomu vještaci pri izračunu štete trebaju uzeti u obzir rizike, a na to ukazuje i činjenica da su prema analizi PwC-a iz 2015. ${ }^{62}$ tribunali dosudili $44 \%$ od izračuna štete na temelju DCF metode. Dodatna PwC-ova analiza iz 2017. godine ${ }^{63}$ upućuje na blagi rast trenda prihvaćanja DCF metode kao primjerene metode izračuna štete (predložena je u 11 od 21 analiziranoga slučaja te prihvaćena u 9 predmeta - 42,8\%), no s obzirom na veličinu uzorka kao i činjenicu da je arbitražna zajednica svjesna ograničenja ove metode, moguće je da ju tužitelji predlažu u predmetima za koje je izvjesno da će i biti prihvaćena.

U odnosu na DCF metodu komentar Nacrta članaka o međunarodnoj odgovornosti država ukazuje na to da ova metoda koristi dosta spekulativnih elemenata od kojih neki imaju značajan utjecaj na konačni izračun (npr. promjene u tečaju, inflacija, cijena sirovine/dobara, kamatne stope i drugi komercijalni rizici).

U odnosu na izgubljenu dobit, komentar razlikuje izgubljenu dobit prije datuma utvrđene povrede, od datuma utvrđene povrede do donošenja odluke te buduću izgubljenu dobit i ističe da prva nije od značaja jer se dogodila prije povrede, druga je formulirana u Chorzow standardu i njezin je cilj potpuna reparacija nastale štete dok za buduću izmaklu dobit ističe da se ona

\footnotetext{
$60 \quad$ Wälde (n 39) 1072-1073.

61 International Arbitration damages research - 2015 (n 41).

62 Ibid.

63 International Arbitration damages research - 2017 update (n 42).
} 
dosuđuje u slučajevima kada postoji neka osnova (koncesija ili ugovor) na temelju koje je moguće s razumnom sigurnošću izračunati moguću buduću dobit, tj. dobit nakon donošenja pravorijeka. U tom je dijelu na tužitelju teret dokaza da se s razumnom sigurnošću može dokazati da bi tužitelj ostvario buduću dobit. U pogledu tereta dokaza zanimljiva je odluka tribunala u predmetu Stati c/a Kazahstan, ${ }^{64}$ u kojoj je tribunal postavio visok standard tereta dokaza zaključivši da tužitelj nema pravo na izgubljenu dobit za eksploataciju prirodnoga plina na polju koje je tek trebao eksploatirati. U predmetu RosInvest c/a Ruska Federacija ${ }^{65}$ tribunal je dosudio samo štetu u vidu cijene dionica uvećane za kamate jer je došao do zaključka da je postojala velika mogućnost da će društvo prestati postojati. ${ }^{66}$

Unatoč svemu navedenomu ova je metoda iznimno privlačna tužiteljima jer omogućava ostvarivanje značajnoga iznosa naknade štete. To potvrđuje i studija Credibility Internationala iz 2014. godine ${ }^{67}$ prema kojoj je DCF metoda bila metoda evaluacije štete u 10 od 30 predmeta koji su se vodili pred ICSID-om i u kojima je dosuđen najviši iznos štete.

Slijedom navedenoga ne iznenađuje da je DCF metoda, koja uključuje i izmaklu buduću dobit, omiljena metoda izračuna štete tužitelja, ali s obzirom na to da tribunali nisu vezani ranijim odlukama, hoće li ju tribunal u pojedinom predmetu prihvatiti, ovisit će o uvjerljivosti prezentiranih dokaza, vještačkoga nalaza, ali i interpretaciji tribunala što se ima smatrati razumnom sigurnošću u odnosu na buduću dobit.

Do odluke tribunala u predmetu Process and Industrial Developments Lim. c/a Ministarstvo mineralnih sirovina Federalne Vlade Nigerije ${ }^{68}$ od 31. siječnja 2017. u odnosu na pitanje buduće izmakle dobiti praksa i teorija relativno su se slagale da je buduću dobit moguće dosuditi primjenom DCF metode samo kada osnova za buduću izmaklu dobit proizlazi iz dugoročno reguliranoga odnosa kao što je npr. ugovor o koncesiji i kada se s razumnom sigurnošću može utvrditi kolika bi ta buduća dobit bila (dakle da je buduća izmakla dobit izvjesna, nije špekulativna, da će se vjerojatno ostvariti i ne predstavlja samo razumno predviđanje - izračun buduće dobiti proizlazi iz konkretnih parametara utvrđenih iz poslovanja investitora ${ }^{69}$ ).

U gore naznačenom predmetu Process and Industrial Developments Limited (P\&ID) i Ministarstvo mineralnih sirovina Federalne Vlade Nigerije u siječnju 2010. godine zaključili su ugovor o koncesiji kojim se Nigerija obvezala od kraja 2011. godine nadalje, idućih dvadeset godina, opskrbljivati P\&ID mokrim plinom, a P\&ID se obvezao izgraditi postrojenje koje će obrađivati mokri plin i $85 \%$ obrađenog plina vraćati Vladi Nigerije. Ugovor je unatoč malom

64 Anatolie Stati, Gabriel Stati, Ascom Group SA and Terra Raf Trans Traiding Ltd v Republic of Kazakhstan, SCC Case No V116/2010 (19 December 2013) 367-368.

65 RosInvestCo UK Ltd $v$ The Russian Federation, SCC Case No V079/2005 (12 September 2010).

66 Wolfgang Alschner, 'Aligning Loss and Liability: Towards an Integrated Assessment of Damages in Investment Arbitration' in Carpenter T, Jansen M and Pauwelyn J (eds), The Use of Economics in International Trade and Investment Disputes (Cambridge University Press 2017).

67 Study of Damages in International Center for the Settlement of Investment Disputes Cases (Credibility International, June 2014) <www.credibilityinternational.com/wp-content/uploads/2014/06/Credibility-ICSID-Damages-Study-June-2014-1.pdf > pristupljeno 19. srpnja 2021.

68 Process and Industrial Developments Ltd $v$ The Ministry of Petroleum Resources of the Federal Republic of Nigeria (Ad hoc arbitration, 31 January 2017) <https://jusmundi.com/fr/document/decision/pdf/en-process-and-industrial-developments-ltd-v-theministry-of-petroleum-resources-of-the-federal-republic-of-nigeria-final-award-tuesday-31st-january-2017> pristupljeno 19. srpnja 2021. 
postotku plina koji je P\&ID imao zadržati bio lukrativan zbog nusproizvoda koji se dobivaju obradom mokroga plina. P\&ID je stupio u kontakt s lokalnim vlastima te je do svibnja 2010. rezervirao 50 hektara zemljišta. P\&ID je također osigurao financiranje projekta - novac za izgradnju postrojenja i projekt $\mathrm{i}$ to je u glavnome bilo sve što je P\&ID napravio. Nigerijska vlast nije postavila cjevovode koje je trebala postaviti kako bi osigurala dostavu mokroga plina, P\&ID je pokušao pregovarati s Vladom Nigerije, no pregovori nisu urodili plodom pa je u ožujku 2013. pokrenuo arbitražu zbog kršenja ugovora o koncesiji koji je u sebi sadržavao i arbitražni sporazum. P\&ID nije kupio zemljište, nije započeo ni izgradio postrojenje te nikada nije razvio ili radio drugi sličan projekt. Unatoč navedenomu, primjenom DCF metode, tribunal je P\&ID dosudio više od 6 milijardi američkih dolara (6.597.000.000\$) naknade štete s kamatama tekućim od donošenja odluke do plaćanja. Dosuđena naknada štete najvećim dijelom čini upravo izmaklu buduću dobit. Naime, tijekom postupka P\&ID sam je naveo da su realni materijalni troškovi iznosili 40 milijuna američkih dolara. Nigerija odbija platiti po pravorijeku iznos koji sada premašuje 9 milijardi dolara s kamatama i čini 20\% nigerijskih rezervi od nafte te se i dalje bori protiv ovrhe tvrdeći da je u konkretnom predmetu riječ o korupciji kako na strani tužitelja tako i na strani tadašnje nigerijske vlade. Tribunal je u dijelu koji se odnosi na naknadu štete rekao da je P\&ID ovlašten tražiti naknadu štete koja će ga dovesti u poziciju u kojoj bi bio da nije bilo povrede od strane nigerijske vlade. Pri tomu je "dovoljno utvrditi bi li P\&ID bio u stanju izvršiti vlastite ugovorne obveze, a ne je li ih i izvršio" (t. 44. odluke). Ovo je stav u odnosu na visinu naknade štete, metodu i odnos prema budućoj dobiti koji u najmanju ruku iznenađuje i koji je suprotan dosadašnjoj praksi. Iako ovo nije tema ovoga rad i sama odluka o nadležnosti u kojoj je sam tribunal odlučivao o valjanosti arbitražnog sporazuma kontroverzna je s aspekta negativnog efekta kompetenz - kompetenz načela i ovlasti tribunala da odlučuje o valjanosti ugovora na temelju kojega je ustanovljena njegova nadležnost. Treba imati u vidu da je ovdje riječ o trgovačkoj arbitraži, a ne međunarodnoj investicijskoj arbitraži, ali to nije relevantno za izračun visine štete jer je i u investicijskim arbitražama u pozadini često raskid ugovora o koncesiji ili npr. oduzimanje dozvole za rad, samo je osnova za odgovornost države drugačija - ona proizlazi iz međunarodnog ugovora kojim se štite prava stranog investitora i međunarodnog običajnog prava. Nadalje, kao što je spomenuto, ako BIT ili multilateralni ugovor sadrži umbrella clause privatnopravni odnos moguće je rješavati i u investicijskoj arbitraži, dakle po dvije osnove, tj. voditi paralelne postupke.

Iz svega navedenog vidljivo je da se stranke i vještaci koje stranke angažiraju značajno razlikuju u pristupu izračunu visine štete, no tribunali sve više preuzimaju proaktivnu ulogu te postavljanjem dodatnih zadataka vještacima i definiranjem relevantnih parametara pokušavaju premostiti jaz između izračuna vještaka koji je angažirao tužitelj i koji je angažirala tužena država. S obzirom na činjenicu da tribunali nisu vezani ranijim odlukama u arbitražnim ili sudskim postupcima i proaktivan pristup stranaka i kvaliteta vještaka će također biti iznimno važni za ishod spora u odnosu na visinu dosuđene štete ako tribunal utvrdi povredu. 


\section{UTVRĐIVANJE VISINE NAKNADE ŠTETE U ODNOSU NA UTVRĐENE POVREDE (NEIZRAVNO IZVLAŠTENJE, NATIONAL TREATMANT, UMBRELLA CLAUSE I FET STANDARD)}

Dosadašnja rasprava obuhvatila je mnoga pitanja u odnosu na izravno izvlaštenje kao i genezu odredbi u BIT-ovima u odnosu na tržišnu naknadu kada tribunal utvrdi da je došlo do izravnoga izvlaštenja.

Kao što je već spomenuto po pitanju naknade štete za izvlaštenje 60 -ih i posebno 70 -ih godina prošloga stoljeća postojala je tenzija dvaju pristupa - onoga koji su zagovarale razvijene države koje su se zalagale za primjenu Hullove formule i onoga koji proizlazi iz Novoga ekonomskog poretka koji su zagovarale zemlje u razvoju i nerazvijene zemlje koje su se zalagale za primjenu Calvove doktrine tj. da se naknada ravna prema nacionalnom pravu zemlje koja je počinila povredu kako ne bi bilo razlike u obeštećenju između stranaca i domaćih osoba (fizičkih i pravnih). Prevladao je pristup koji su zagovarale razvijene zemlje. U nastavku se daje osvrt na otvorena pitanja u odnosu kada su utvrđene druge povrede, a ne izravno izvlaštenje, i način izračuna naknade štete.

\section{NEIZRAVNO IZVLAŠTENJE - ŠULJAJUĆE IZVLAŠTENJE (CREEPING EXPROPRIATION) I REGULATORNO IZVLAŠTENJE}

Neizravno izvlaštenje je povreda na koju se investitori današnjice znatno češće pozivaju nego na izravno izvlaštenje. Šuljajuće izvlaštenje predstavlja vrstu neizravnog izvlaštenja u kojem država višestrukim postupanjem obezvrjeđuje investiciju. To konkretno znači da je predmet investicije, tj. investicija i dalje u vlasništvu investitora, država nije oduzela vlasništvo nad investicijom kao što bi napravila u izravnom izvlaštenju, ali je država nizom npr. poreznih mjera, propisa i upravnih akata toliko umanjila i onemogućila investiciju da je ona zbog svih tih mjera postala bezvrijedna. Kao što je vidljivo, kod takve će povrede teško biti utvrditi kada je točno počinjena povreda jer se povreda sastoji od niza mjera koje u svojoj ukupnosti dovode do uništenja i potpunog obezvređenja investicije.

Regulatorno izvlaštenje je slično šuljajućem, no kod ove podvrste neizravnog izvlaštenja riječ je isključivo o zakonodavnoj funkciji države koja dovodi do propasti investicije i posljedično njezina obezvrjeđenja. Kao što je vidljivo u ovoj podvrsti neizravnog izvlaštenja naglasak je na propisima koje država donosi dok je kod šuljajućeg izvlaštenja naglasak kako na pojedinačnim aktima države, tako i općim aktima koji imaju razoran učinak na investiciju. Treba imati u vidu da svaka regulatorna funkcija države ne predstavlja regulatorno izvlaštenje kao i činjenicu i da sam sporni propis nije u cijelosti izvlašćujući pa će stoga biti potrebno utvrditi u kojem dijelu je država prešla granicu dopuštenog reguliranja i kada je točno prešla u sferu regulatornog izvlaštenja. To će se reflektirati i na visinu eventualne štete koja je investitoru nastala jer samo u dijelu koji je protivan međunarodnom ugovoru može se izračunavati i eventualna šteta.

Merill također naglašava da se u slučaju šuljajućega i regulatornog izvlaštenja naknada štete ne može sastojati u punom obeštećenju kao kod izravnog izvlaštenja već bi pravilan pristup 
bio krenuti od Chorzow standarda tako da se utvrdi vrijednost investicije u trenutku kada je sporna mjera stupila na snagu te da se usporedi s vrijednošću koju bi investicija imala da nije donesena sporna mjera, odluka ili propis ili da je država donijela u cijelosti dopuštenu mjeru, odluku ili propis pri čemu je posebno izazovno utvrditi u kojem je dijelu država prekoračila svoje suvereno pravo da donosi propise jer samo u dijelu u kojem je propis protivan međunarodnoj obvezi investitor može potraživati naknadu štete. Pri tomu treba imati u vidu da investitor nije izgubio vlasništvo nad investicijom pa kompenzacija ili treba biti umanjena za preostalu vrijednost investicije ili investitor treba prenijeti investiciju na državu koja plaća kompenzaciju. $^{70}$

\section{ODABIR METODA IZRAČUNA NAKNADE ŠTETE KOD POVREDE UMBRELLA CLAUSE, NATIONAL TREATMANT I FET STANDARDA}

Za razliku od izvlaštenja, međunarodni bilateralni i multilateralni ugovori za zaštitu stranih investicija ne sadrže odredbu o tome na koju bi naknadu investitori bili ovlašteni. Kao što je već spomenuto, u odnosu na izvlaštenje navedeni ugovori najčešće preuzimaju Hullovu formulu i propisuju da je u slučaju izvlaštenja strani investitor ovlašten na tržišnu naknadu koja mora biti isplaćena promptno i određena u poštenom i pravičnom postupku. U odnosu na povredu FET standarda, diskriminaciju stranih investitora u odnosu na domaće investitore ili umbrella clause kojom se ugovorna obveza države „diže“ na razinu međunarodne obveze jer država preuzima obvezu ispunjavanja svojih ugovornih obveza međunarodnim ugovorom, međunarodni ugovori ne sadrže odredbu o načinu obeštećenja.

I kod navedenih povreda pravilno bi bilo poći od Chorzow standarda i zapitati se kakva bi bila pozicija investitora da država nije počinila povredu, ali da bi se standardi koji su razvijeni za određivanje naknade za izvlaštenje primijenili i na ostale standarde zaštite potrebno je usporediti situaciju nakon povrede (ex post) sa situacijom koja bi egzistirala da vlada nije pri provođenju određene politike počinila procesnu ili materijalnopravnu povredu koja predstavlja povredu naznačenih međunarodnih standarda zaštite. Pri tomu, pri određivanju kompenzacije za povredu treba imati u vidu politiku (mjeru, propis, odluku itd.) koja se osporava i treba ju razviti u budućnost, ali na način da je ta mjera/propis/odluka bez povrede na koju investitor upire.

Tako u odnosu na zabranu diskriminiranja stranih investitora u odnosu na domaće investitore (tzv. national treatment) prvenstveno treba utvrditi je li došlo do očite diskriminacije stranog investitora u odnosu na domaćeg jer u tom slučaju pri određivanju naknade štete treba usporediti domaćega i stranoga investitora kao i diskriminatorne mjere te utvrditi u kojoj bi poziciji strani investitor bio da tih mjera nije bilo. $S$ druge strane, ako je riječ o nenamjernim mjerama koje imaju diskriminirajući efekt na stranoga investitora potrebno je razmotriti kakva bi bila situacija da tih mjera nije bilo, ali samo do mjere u kojoj su one diskriminirajuće. Od trenutka otkad bi država u takvoj hipotetskoj situaciji prilagodila sporne mjere ili bi imala legitimni interes da ih donese investitor više ne bi imao pravo na naknadu štete. Treba imati $\mathrm{u}$ vidu da upravo kod ove povrede, budući da nema jasnih pravila u izvorima međunarodnoga 
prava, a ni opsežne prakse, tribunali itekako ovise o mišljenjima eksperata pri čemu stranke ponekad daju nedovoljne i nepotpune upute što dodatno otežava određivanje visine naknade štete. Osim navedenoga, ponekad ova povreda dolazi u kombinaciji s utvrđenim izvlaštenjem pa se tribunali priklanjaju načinu izračuna naknade štete za izvlaštenje. U predmetima Occidental c/a Ekvator ${ }^{71}$ i Feldamn c/a Meksiko ${ }^{72}$ država je odbila povrat poreza stranim investitorima iako je dopustila povrat poreza domaćima. U tim je predmetima tribunal jednostavno izračunao visinu štete jer se ona sastojala u povratu poreza na koju bi tužitelj imao pravo da nije bio diskriminiran. U predmetu Feldman c/a Meksiko tribunal je odbio primijeniti izračun tržišne vrijednosti kako se to primjenjuje pri izračunu naknade štete kod izvlaštenja kao i dosuditi izgubljenu dobit jer je navode tužitelja ocijenio špekulativnima. U predmetu Myers c/a Kanada ${ }^{73}$ u kojem je Kanada počinila povredu NAFTA-e kada je zatvorila granicu za izvoz opasnih otrova tribunal je detaljno analizirao sve činjenice u odnosu na naknadu štete i simulirao u kojem bi položaju Myers bio da nije došlo do zatvaranja granice za izvoz i pri tomu išao do toga da je predviđao koliko bi Myers bio uspješan na međunarodnim javnim natječajima da nije bilo sporne mjere, no nije uzeo u obzir da pri i ovakvoj povredi tribunali imaju na raspolaganju nekoliko mjera kao što su restitucija i satisfakcija. Naknade štete nije jedina mjera koju bi tribunali trebali imati u vidu, posebno što visoke naknade štete nisu uvijek opravdane i mogu imati značajan utjecaj na cjelokupnu ekonomsku situaciju države čime se otvara i pitanje vjerodostojnosti arbitraže kao načina rješavanja sporova. ${ }^{74}$

FET standard ili kako ga često nazivaju „uspavana ljepotica investicijskih arbitraža“75 postao je popularna osnova za pokretanje arbitraže u posljednjih 30-ak godina te je pretekao pojavnošću izvlaštenje.

I u slučaju povrede FET standarda nema razloga izbjegavati primjenjivati sve modalitete reparacije štete kako to predviđa Nacrt članaka o međunarodnoj odgovornosti država, dakle i restituciju i satisfakciju, a ne samo kompenzaciju, tj. naknadu za počinjenu štetu.

Pa ipak, u odnosu na praksu tribunala, naknada je štete najčešća i njezino određivanje varira od naknade štete određene prema pravilima za izvlaštenje (kada povreda dovodi do potpune propasti investicije) do naknade štete kako bi ona bila određena za klasični građanskopravni delikt jer međunarodni ugovori ne sadrže odredbe kako se ima odrediti reparacija. Upravo zbog toga razloga tribunali imaju široku diskreciju u donošenju odluka. ${ }^{76}$

Tako je npr. tribunal u predmetu CMS c/a Argentina ${ }^{77}$ zaključio da se za određivanje naknade štete ima primijeniti tržišna naknada (iako nije utvrdio da bi investicija bila izvlaštena) jer je, prema stavu tribunala, riječ o povredama koje imaju dugotrajne posljedice i gubitak - dakle

71 Occidental Petroleum Corp and Occidental Exploration and Production Co v Republic of Ecuador, ICSID Case No ARB/06/11 (5 October 2012).

Marvin Roy Feldman Karpa v The United Mexican States, ICSID Case No ARB(AF)/99/1 (16 December 2002).

SD Myers Inc v Canada, (NAFTA arbitration, UNCITRAL rules, Ad hoc arbitration, 30 December 2002) <www.italaw.com/ cases/969> pristupljeno 19. srpnja 2021. 5 Transnational Dispute Management <www.transnational-dispute-management.com/article asp?key=593〉 pristupljeno 19. srpnja 2021. 
učinak izvlaštenja. U predmetu Petrobrat c/a Kirgistan ${ }^{78}$ tribunal je utvrdio da je došlo do povrede FET standarda te dosudio otprilike $75 \%$ utuženog zahtjeva navodeći da bi Petrobrat naplatio račune koji su utvrđeni sudskom odlukom, bez obzira na slabu platežnu moć trgovačkog društva u državnom vlasništvu koje je bilo dužnik po tim računima, da nije bilo intervencije države. Naplata bi bila izvršena u stečajnom postupku, no činjenica da je tribunal umanjio visinu naknade štete za $25 \%$ iako je tužitelj u rukama imao sudsku odluku koja potvrđuje postojanje duga, pokazuje da je tribunal uzeo u obzir rizik da se tužitelj ne bi u cijelosti naplatio pa je tako u biti reflektirao rizik u parnici (koji ima svaka stranka pa tako i strani investitori što može utjecati i na visinu štete u arbitražnom postupku) s rizikom vezanim uz ovrhu u kojoj nije sigurno da će se ovrhovoditelj u cijelosti namiriti. Nema dvojbe da takav rizik postoji i u stečajnom postupku. Navedeni rizici su prisutni i kod arbitražnih postupaka koje strani investitori pokreću radi uskrate pravde (Denial of Justice). Niti u tim postupcima naknada štete ne može odgovarati onomu što strani investitor potražuje jer bi se time u cijelosti anulirao rizik koji objektivno postoji u sudskom ili drugom postupku za koji investitor tvrdi da je doveo do povrede navedenoga međunarodnopravnog standarda. ${ }^{79}$

U odnosu na legitimna očekivanja kao podvrstu FET standarda na koju se tužitelji često pozivaju treba pri određivanju visine naknade štete imati u vidu nekoliko činjenica. Prva je da legitimna očekivanja koja bi investitor imao, kao. npr. da će zaključiti ugovor o koncesiji s državom, nisu isto što i ugovorno pravo jer ugovor nije zaključen. Nadalje, kao što strani investitor može imati legitimna očekivanja prema državi i sama tužena država ima legitimno pravo razvoja vlastite politike pa ta očekivanja kao takva treba sučeliti (poznata je doktrina Margine of Appreciation prema kojoj država do jedne mjere ima pravo i dužnost u izvršavanju svoje suverene vlasti regulirati pojedina područja, a koja se nadovezuju upravo na navedeno legitimno pravo razvoja). U analizi činjenica i legitimnih očekivanja investitora i legitimnih prava države pitanje je hoće li tribunal uopće utvrditi povredu, a čak i ako ju i utvrdi, visina naknade štete trebala bi biti određena sukladno historijskim troškovima jer u ovakvim slučajevima ne postoji ugovor i pitanje je bi li bio zaključen, pa stoga ne postoji ni ugovorna obveza države u tom smislu. ${ }^{80}$

U odnosu na umbrella clause naknada može biti određena prema principima za naknadu kod izvlaštenja, ako bi povreda bila takva da bi njezine posljedice odgovarale posljedicama izvlaštenja, ili može biti određena kako bi bila određena u svakom sudskom postupku. Moguće je da naknada štete određena prema principima za određivanje naknade za izvlaštenje bude niža jer se pri izračunu naknade štete uzima tzv. rizik države, rizici vezani uz samu investiciju što će se sve razmjerno reflektirati na diskontnu stopu dok sudovi, pri određivanju naknade štete radi nedopuštenoga raskida ugovora dosuđuju sva buduća plaćanja koja su dospjela, moguće alternativne zarade i buduću dobit. U praksi ovi sustavi zajedno egzistiraju, no trebalo bi dati prednost određivanju naknade štete prema principima za izvlaštenje jer smisao međunarodnopravne zaštite investitora nije baviti se ugovornim obvezama, već povredama koje predstavljaju zloupotrebu javnih ovlasti države na štetu investitora. Dakle, čak i kada sam me-

\footnotetext{
78 Petrobart Ltd $v$ The Kyrgyz Republic, SCC Case No 126/2003 (29 March 2005).

79 Wälde (n 39) 1087-1089. 
đunarodni ugovor sadrži umbrella clause ona se treba interpretirati u svjetlu kvaziizvlaštenja, a ne u svjetlu povrede ugovorne obveze. ${ }^{81}$

\section{ZAKLJUČAK}

Iz svega navedenoga može se zaključiti da je, unatoč i ostalim modalitetima reparacije štete, međunarodnoj investicijskoj arbitraži imanentna naknada štete u vidu novčane kompenzacije koju će odrediti tribunal. Ta šteta uključuje stvarnu štetu, moralnu tj. nematerijalnu štetu i izgubljenu buduću dobit. Pri tomu na visinu štete utječe pravna kvalifikacija povrede, datum otkad se računa šteta (ali koji je podložan arbitrarnom određivanju) i odabranoj metodi izračuna štete. Nadalje, iako međunarodni ugovori propisuju što je naknada štete u slučaju izravnog izvlaštenja (tržišna naknada) u slučaju ostalih povreda kao npr. FET standarda, to je prepušteno tribunalu. Tribunali također vrlo često moraju u okviru određivanja visine naknade štete odlučiti koja je metoda izračuna visine štete najbolja s obzirom na utvrđeno činjenično stanje, od kojeg trenutka se smatra da je nastupila šteta investitoru i u kojoj mjeri, vodeći računa da pri tomu ne dopuste da dođe do neopravdanog obogaćenja, a što bi se moglo reći da je situacija u opisanom predmetu Process and Industrial Developments Limited (P\&ID) c/a Ministarstvo mineralnih sirovina Federalne Vlade Nigerije gdje je tribunal dosudio ukupnu izgubljenu buduću dobit u iznosu većem od 6 milijardi US dolara s kamatom tekućom do isplate iako je tužitelj za razvoj investicije potrošio 40 milijuna dolara - i to samo za razvoj projekata i nije nikada obavljao djelatnost koja je bila predmet investicije što znači da nije bilo usporednih podataka na temelju kojih bi se mogli izračunati očekivani budući prihodi primjenom DCF metode.

Sva navedena sporna pitanja utječu na visinu utužene i dosuđene štete što je vidljivo iz statističke obrade podataka 220 predmeta dostupnih na UNCTAD-ovim mrežnim stranicama. Statistička obrada pokazuje da tribunali dosuđuju tek $37 \%$ od utuženog iznosa. Ta činjenica dokazuje da pitanje visine naknade štete nije jednodimenzionalno i da će o vještini eksperata i stranaka ovisiti i uspješnost u sporu. Što će stranke bolje utvrditi činjenice, pravno kvalificirati spor i odrediti varijable relevantne za izračun naknade štete, to će i vještaci lakše odabrati metodu izračuna visine štete i pripremiti bolji vještački nalaz koji će u slučaju tuženika često uključivati ne samo navode kojima se osporava izračun tužiteljevog vještaka nego i vlastiti izračun eventualne štete ako se utvrdi povreda.

Konačno, poznavanje svih aspekata određivanja visine naknade štete (ali i aktivno sudjelovanje prvenstveno stranaka - posebno tuženika jer je tuženik često pasivniji od tužitelja) nužno je u postupku međunarodne investicijske arbitraže kako bi se izbjegle odluke kao ona u predmetu P\&ID c/a Nigerija koja će zasigurno biti rado citirana od strane tužitelja u investicijskim arbitražnim sporovima, ali koja je u mnogim aspektima kontroverzna. 


\section{BIBLIOGRAFIJA}

1. - - Expropriation: UNCTAD Series on Issues in International Investment Agreements II (United Nations 2012) <https://unctad.org/en/Docs/unctaddiaeia2011d7_en.pdf> pristupljeno 19. srpnja 2021.

2. Abadala MA, 'Chorzow's Standard Rejuvenated: Assessing Damages in Investment Treaty Arbitration' (2008) 25(1) Journal of International Arbitration 103

3. Alschner W, 'Aligning Loss and Liability: Towards an Integrated Assessment of Damages in Investment Arbitration' in Carpenter T, Jansen M and Pauwelyn J (eds), The Use of Economics in International Trade and Investment Disputes (Cambridge University Press 2017)

4. Antony J, 'Umbrella Clauses Since SGS V. Pakistan And SGS V. Philippines: A Developing Consensus' (2013) 29(4) Arbitration International 607

5. Dolzer R and Schreuer C, Principles of International Investment Law (2nd edn, OUP 2012)

6. Hirsch M, 'Sources of International Investment Law' in Bjorklund AK and Reinisch A (eds), International Investment Law and Soft Law (Edward Elgar Publishing 2012)

7. Hoffmann AK, 'Indirect Expropriation' in Reinisch A (ed), Standards of Investment Protection (OUP 2008)

8. Houtte $\mathrm{H}$ and McAsey B, 'Future Damages in Investment Arbitration: A Tribunal with a Crystal Ball?' in Caron DD and others (eds), Practising Virtue: Inside International Arbitration (OUP 2015)

9. Kläger R, "Fair and Equitable Treatment" in International Investment Law (Cambridge University Press 2011)

10. MacGibbon IC, 'Estoppel in International Law' (1958) 7(3) The International and Comparative Law Quarterly 468 <www.jstor.org/stable/755277> pristupljeno 19. srpnja 2021.

11. Mehren RB, 'International Arbitral Tribunal: Award on the Merits in Dispute Between Texaco Overseas Petroleum Company/California Asiatic Oil Company and the Government of the Libyan Arab Republic (Compensation for Nationalized Property)' (1978) 17(1) International Legal Materials 1 <www.jstor.org/stable/20691828?read-now=1\&seq=3\#page_scan_tab_contents > pristupljeno 19. srpnja 2021.

12. Reinisch A (ed), Standards of Investment Protection (OUP 2008)

13. Sabahi B, Compensation and Restitution in Investor-State Arbitration Principles and Practice (OUP 2011)

14. Schreuer CH, 'Fair \& Equitable Treatment' [2005] 5 Transnational Dispute Management <www. transnational-dispute-management.com/article.asp?key=593> pristupljeno 19. srpnja 2021.

15. Sinclair AC, 'The Origins of The Umbrella Clause in the International Law of Investment Protection' (2014) 20(4) Arbitration International 411

16. Sinh B, 'Compensation Under International Investment Law Arbitration in Investor-State Infrastructure Contracts' (master thesis, Faculty od Law, University of Oslo 2017) <http://urn.nb.no/ URN:NBN:no-63194> pristupljeno 19. srpnja 2021.

17. Trenor JA, The Guide to Damages in International Arbitration (2nd edn, Law Business Research 2017)

18. Wälde T and Sabahi B, 'Compensation, Damages, and Valuation' in Muchlinski P, Ortino F and Schreuer C (eds), The Oxford Handbook of International Investment Law (OUP 2008) 


\section{PROPISI I DOKUMENTI}

1. Central America Free Trade Agreement (CAFTA) <https://ustr.gov/trade-agreements/free-tradeagreements/cafta-dr-dominican-republic-central-america-fta/final-text $\rangle$ pristupljeno 19. srpnja 2021.

2. Konvencija o priznanju i ovrsi stranih arbitražnih pravorijeka (NN-MU 4/1994) (HR)

3. Konvencija o rješavanju investicijskih sporova između država i državljana drugih država (NN-MU 2/1998, 13/1998) (HR)

4. North American Free Trade Agreement (NAFTA) <www.sice.oas.org/trade/nafta/naftatce.asp> pristupljeno 19. srpnja 2021.

5. Statute of the International Court of Justice (International Court of Justice) <www.icj-cij.org/en/ statute> pristupljeno 19. srpnja 2021.

6. The Comprehensive and Economic Trade Agreement (CETA) <https://ec.europa.eu/trade/policy/ in-focus/ceta/ceta-chapter-by-chapter/> pristupljeno 19. srpnja 2021.

7. The International Energy Charter - Consolidated Energy Charter Treaty: With Related Documents (last updated 15 January 2016) <www.energycharter.org/fileadmin/DocumentsMedia/Legal/ECTC-en.pdf> pristupljeno 19. srpnja 2021.

8. United Nations, Resolution adopted by the General Assembly A/RES/56/83 (28 January 2002) <https://undocs.org/A/RES/56/83> pristupljeno 19. srpnja 2021.

\section{PRESUDE I DRUGE ODLUKE}

1. ADC Affiliate Limited and ADC \& ADMC Management Limited v The Republic of Hungary, ICSID Case No ARB/03/16 (2 October 2006)

2. Anatolie Stati, Gabriel Stati, Ascom Group SA and Terra Raf Trans Traiding Ltd v Republic of Kazakhstan, SCC Case No V116/2010 (19 December 2013)

3. Anglo-Iranian Oil Co case (jurisdiction), judgment of July 22nd, I952: ICJ Reports I952 p 93

4. Antoine Goetz and others v. Republic of Burundi, ICSID Case No ARB/95/3 (10 February 1999)

5. Case Concerning the Factory at Chorzów (Claim for Indemnity) (Jurisdiction) [1927] PCIJ Ser A No 9 (26 July 1927)

6. CMS Gas Transmission Co v The Argentine Republic, ICSID Case No ARB/01/8 (12 May 2005)

7. Generation Ukraine Inc v Ukraine, ICSID Case No ARB/00/9 (16 September 2003)

8. Georg Gavrilovic and Gavrilovic doo v Republic of Croatia, ICSID Case No ARB/12/39 (26 July 2018)

9. LFH Neer and Pauline Neer (USA) v United Mexican States, (15 October 1926) Reports of International Arbitral Awards (2006, vol IV, pp 60-66)

10. Marvin Roy Feldman Karpa v The United Mexican States, ICSID Case No ARB(AF)/99/1 (16 December 2002)

11. Occidental Petroleum Corp and Occidental Exploration and Production Co v Republic of Ecuador, ICSID Case No ARB/06/11 (5 October 2012)

12. Petrobart Ltd $v$ The Kyrgyz Republic, SCC Case No 126/2003 (29 March 2005)

13. Process and Industrial Developments Ltd $v$ The Ministry of Petroleum Resources of the Federal Republic of Nigeria (Ad hoc arbitration, 31 January 2017) <https://jusmundi.com/fr/document/decision/pdf/ 
en-process-and-industrial-developments-ltd-v-the-ministry-of-petroleum-resources-of-the-federal-republic-of-nigeria-final-award-tuesday-31st-january-2017> pristupljeno 19. srpnja 2021.

14. RosInvestCo UK Ltd v The Russian Federation, SCC Case No V079/2005 (12 September 2010)

15. SD Myers Inc v Canada, (NAFTA arbitration, UNCITRAL rules, Ad hoc arbitration, 30 December 2002) <www.italaw.com/cases/969> pristupljeno 19. srpnja 2021.

16. SGS Société Générale de Surveillance SA v Islamic Republic of Pakistan, ICSID Case No ARB/01/13 (6 August 2003)

17. SGS Société Générale de Surveillance SA v Republic of the Philippines, ICSID Case No ARB/02/6 (17 December 2007)

\section{MREŽNI IZVORI}

1. Database of ICSID Member States (International Centre for Settlement of Investment Disputes) <https://icsid.worldbank.org/about/member-states/database-of-member-states> pristupljeno 19. srpnja 2021.

2. Gouyon Matignon L, 'Estoppel in Public International Law' (Space Legal Issues, 19 June 2019) <https://www.spacelegalissues.com/estoppel-in-public-international-law/> pristupljeno 19. srpnja 2021.

3. International Arbitration damages research - 2015 (PwC, 2015) <www.pwc.co.uk/forensic-services/ disputes/insights/assets/pdf/2015-international-arbitation-damages-research.pdf> pristupljeno 19. srpnja 2021.

4. International Arbitration damages research - 2017 update (PwC, 2017) <www.pwc.co.uk/forensic-services/assets/pwc-international-arbitration-damages-research-2017.pdf > pristupljeno 19. srpnja 2021.

5. Investment Dispute Settlement Navigator (United Nations Conference on Trade and Development, Investment Policy Hub) 〈https://investmentpolicy.unctad.org/investment-dispute-settlement> pristupljeno 19. srpnja 2021.

6. Status: Convention on the Recognition and Enforcement of Foreign Arbitral Awards (New York, 1958) (the "New York Convention") <https://uncitral.un.org/en/texts/arbitration/conventions/ foreign_arbitral_awards/status2> pristupljeno 19. srpnja 2021.

7. Study of Damages in International Center for the Settlement of Investment Disputes Cases (Credibility International, June 2014) <www.credibilityinternational.com/wp-content/uploads/2014/06/ Credibility-ICSID-Damages-Study-June-2014-1.pdf> pristupljeno 19. srpnja 2021. 


\section{DETERMINING THE AMOUNT OF DAMAGES AWARDED IN INTERNATIONAL INVESTMENT ARBITRATION AS REGARDS THE DAMAGE CAUSED AND DAMAGES}

\section{Summary}

International investment arbitration as an alternative dispute resolution mechanism for resolving disputes between foreign investors and host states is also a favourite dispute resolution for investors. It consist of three parts, all of which can be resolved separately. These are jurisdiction, merits and damages. Consequently, it is possible for a tribunal to render one, two or even three arbitral awards, depending on the tribunal decision to bifurcate/trifurcate the proceedings or not. This shows the complexity of each of the stages of the arbitration proceeding. The paper deals with the issue of reparation, specifically compensation for damage caused as the main form of reparation for damage. It gives an overview of the legal issues affecting the amount of awarded damages, the main methods for calculating damages, as well as the applicable case-law and statistics in relation to the legal issues and calculating methods. The paper argues that only a proactive and inclusive approach in respect to determining damages including a detailed fact analysis for legal qualification of the dispute and determination of the best damages assessment methods, can give satisfactory results.

Keywords: $\quad$ arbitration, methods for assessing damages

\section{(c) (1) (8)}

This work is licensed under a Creative Commons

Attribution-NonCommercial 4.0 International License.

Jadranka Osrečak, LLM, Deputy Municipal State Attorney in Zagreb redirected to State Attorney's Office of the Republic of Croatia, Gajeva 30a, 10000 Zagreb. E-mail address: osrecak@gmail.com. ORCID: https://orcid.org/0000-0003-0156-8725. 